\title{
MORISCOS PENINSULARES, MOROS FILIPINOS Y EL ISLAM EN EL EXTREMO ORIENTAL DEL IMPERIO ESPAÑOL: 2. EDICIÓN DE LA PRIMERA CARTA PARA LA S.C.M.R ACERCA DE LOS MAHOMETANOS DE LAS PHILIPINAS DE MELCHOR DE ÁVALOS (1585)
}

Francisco Franco Sánchez

Isaac Donoso Jiménez

En el volumen anterior de Sharq Al-Andalus. Estudios Mudéjares y Moriscos publicamos el estudio «Moriscos peninsulares, moros filipinos y el islam en el extremo oriental del imperio español: 1. Estudio y edición de la Segunda carta para la S.C.M.R acerca de los mahometanos de las Philipinas de Melchor de Ávalos (1585)». A causa de la gran extensión final del artículo, la redacción nos sugirió dividir en dos partes el trabajo incialmente presentado para su publicación. En la primera se incluyó junto al estudio introductorio (en que que explica la significación histórica y el pensamiento de Melchor de Ávalos), la Segunda carta -o segundo memorial-que le envía a Felipe II como rey de España. Hemos dejado la publicación de la Primera carta para este estudio posterior, debido a que es bastante más extensa que la Segunda.

Recordamos que es enorme el interés de estos memoriales como documento histórico, pero sobre todo como compilación jurídica, pues suponen un compendio de todo el derecho canónico referido al trato que se ha de conceder a los musulmanes, así como a sus propiedades y creencias en los reinos cristianos (de obligada aplicación estatal). Se recogen normativas que se remontan a la Alta Edad Media, así como posteriores al s. XIII. Con ello, entendemos que los dos memoriales se convierten en un obligado punto de referencia para comprender la legislación y el pensamiento antimusulmán en la Baja Edad Media y en la Edad Moderna. 


\section{APÉNDICE DOCUMENTAL}

Manuscrito original, firmado, en el Archivo General de Indias de Sevilla: [Filipinas, leg. 18A, R.3, N.19]. El expediente se compone de dos cartas-tratados con otra introductoria. Las dos cartas fueron editadas bajo el título de «Dos cartas al Rey contra los moros de las Filipinas» por L. HANKE: Cuerpo de documentos del siglo XVI. Sobre los derechos de España en las Indias y las Filipinas. Descubiertos y anotados por Lewis Hanke. Compilador Agustín Millares Carlo, México, Fondo de Cultura Económica, 1943, pp. 65-115. Realizamos una nueva edición de las dos cartas consultando directamente el manuscrito original, teniendo en cuenta los siguientes criterios: se mantiene la ortografía del texto pero se actualizan los acentos a la norma actual; se añaden los signos de puntuación mínimos para una mejor lectura; se escriben en mayúsculas los nombres propios; se redactan en cursiva los textos y citas latinas; no se expanden las palabras abreviadas y se mantiene la división en epígrafes del original. Respecto a las notas explicativas, incluimos varias procedentes de la edición de Hanke, y añadimos otras en torno a las fuentes del derecho canónico y el contexto en el que se gesta el documento.

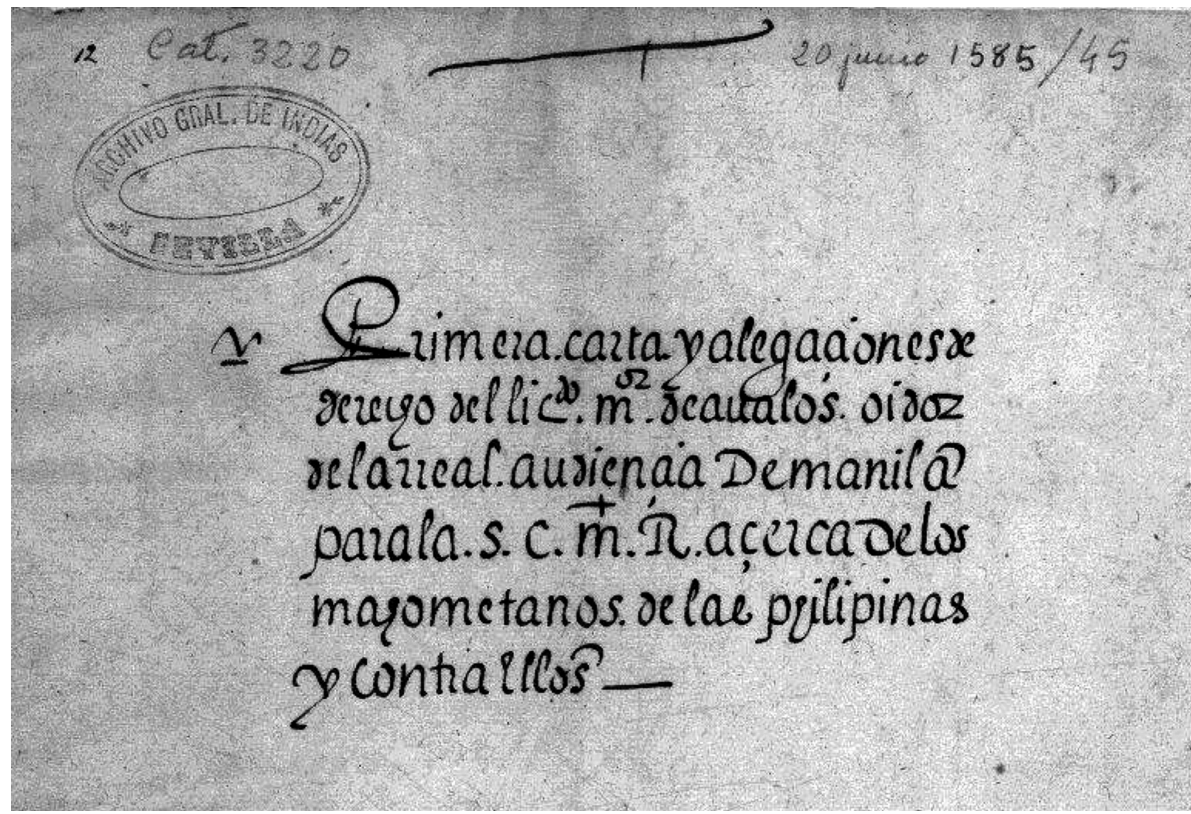

Portada de la Primera carta de Melchor de Ávalos. 


\title{
Primera carta y alegaciones de derecho de lic. $.^{\text {do }} \mathrm{M} .^{\text {or }}$ de Ávalos oidor de la real audiencia de Manila para la S.C.M.R. acerca de los mahometanos de las Philipinas y contra ellos [Manila, 1585]
}

\author{
$\dagger$ \\ SACRA CesÁrea Magestad ReAL
}

1. Entre otras cosas, luego que reçibí en México la provisión de primero oydor de esta Real audiencia de las Yslas Philipinas, escriví a Vuestra Magestad sobre una duda que yo entendía nadie averla tocado, suplicando por declaraçión y consultada instruçión para mejor servir, y fue açerca de lo que se hará de los mahometanos de estas tierras y mares, que están llenas dellos en el archipiélago que se nos señala por distrito, y dixe que llegado acá teniendo la cosa presente, escriviría mi pareçer. No pude hazerlo en los navíos que partieron por principio de Julio del año passado de 84, por ser rezién llegada la Audiencia y no tener la notiçia que aora; quisiera más suffiçiençia para escrivir en cosa tan pesada y para mí difficultosa; supplico a V. M. sea servido de mandar supplir mis ignorançias y poco talento, confiado estoy en la sabiduría del Spiritu Sancto que pareçe habla con V. M. y conmigo; sapientis, cap. $6^{1}, A u-$ dite reges et intelligite; discite iudices finium terrae; assí que conmigo habla este verso postrero, que soy uno de los oydores de este cabo del mundo.

2. Utinam dirigantur viae meae secundum iustificationes tuas, psalmo $118^{2}$; y assí sea todo lo que dixere debaxo de corrección cathólica. Bien se dexa entender que desea V. M. para sus philipenses que le servimos en estas yslas, lo que Sant Pablo deseava y escrivia a sus philipenses de Macedonia: ut sitis sine querela, et simplices filii Dei, sine reprehensione in medio nationis pravae et perversae, inter quas lucetis sicut luminaria in mundo, ad philipenses, cap. $2^{3}$. Plega a la providençia de dios darme fuerças y seso para servirle a V. M., porque siempre parezca que a gastado sus thesoros en esta sancta obra de la conversión, bien empleados, como el apóstol dixo en la misma carta, quia non in vacuum cucurri nec in vanum laboravi ${ }^{4}$.

3. Para fundamento de todo este negoçio y su declaraçión conviene presuponer la conçessión del papa Alexandro 6, el qual por el año de mill y quatroçientos y noventa y tres hizo aquella admirable hazaña nunca vista ni oyda, que puso términos y mojoneras en el çielo y en el ayre entre los valerosíssimos señores Reyes de Castilla y Portugal, fabricando una línea del polo ártico, que es el septemtrión, al polo antártico, que es al medio día; y lo que quiero presuponer de la bula y conçessión, es aver dado y conçedido el pontífiçe y tener V. M. como suçesor de aquellos Reynos el dominio y jurisdiçiones de las Yndias y nuevos mundos; aviendo referido las yslas y tierras firmes descubiertas y por descubrir, halladas y por hallar, conçede la bula por estas palabras: auctoritate omnipotentis dei nobis in beato Petro concessa ac vicarius Jesu Christi, qua fungimur in terris, cum omnibus illarum dominiis, civitatibus, castris, locis et villis, juribusque et jurisdictionibus ac pertinentiis universis, vobis heredibusque et successori-

\footnotetext{
1. Versículo 2.

2. Vers. 5.

3. Vers. 15.

4. C. 2 , vers. 16 .
} 
bus vestris castellae et legionis regibus, in perpetuum thenore praesentium donamus, concedimus et assignamus, vosque et heredes ac successores praefatos illarum dominos cum plena, libera et omnimoda potestate, aucthoritate et jurisdictione facimus, constituimus et deputamus, decernentes, etc. Lo qual, juntamente con lo que el mismo pontífiçe antes dize que se mueve de su çierta sçiencia, motu proprio et de Apostolicae potestatis plenitudine, nos haze creer la validaçión y permanençia de la conçessión, y la buena fee con que V. M. tiene y possee las jurisdiçiones y dominios de estas tierras y mares y de sus gentes. $Y$ lo mismo se puede dezir que aprovaron y confirmaron los sumos pontífiçes que después an sido, pues notorio es aver conçedido muchos indultos y bulas, faboreçiendo la esclareçida obra y edifiçio de la conversión de los infieles; esta bula y conçessión aprueva la opinión de Hostiense y de sus sequaces, in cap. quod super his, devoto ${ }^{5}$, referidos por muchos autores, quod papa etiam in temporalibus habet jurisdictionem in universo apud infideles y la pudo dar y conçeder, como lo dice Gregorio López in dis-

5. Decretales, lib. 3, tít. 34, c. 8. El término "decretalis" -o "epistola decretalis"- se refiere a una carta pontifical que contiene un "decretum", o decisión pontifical. Bajo el nombre de "decretales" se conocen ciertas colecciones, que contienen especial, pero no exclusivamente, decretos pontificales. Estas son las colecciones canónicas de una fecha posterior que el "Decretum" de Graciano (alrededor de 1150), cfr. nota 13. A mediados del siglo XII se consideraba el "Decretum" de Graciano como un "corpus juris canonici", es decir, un código de leyes eclesiásticas entonces en vigor, pero estaba incompleto, pues Papas posteriores habían promulgado muchas leyes con posterioridad; de ahí la necesidad de elaborar nuevas colecciones. Cinco de estas colecciones exhibían legislación pontifical desde el "Decretum" de Graciano hasta el pontificado del Papa Gregorio IX (1150-1227); éstas se conocen como “Quinque compilationes antiquæ". Debido a su importancia se convirtieron en el texto de instrucción canónica en la Universidad de Bolonia. La primera colección, el "Breviarium extravagantium", o resumen de las decretales no incluidas en el "Decretum" de Graciano ("vagantes extra Decretum"), fue obra de Bernardo de Pavía y se compiló entre 1187-1191. La segunda compilación, también llamada "Decretales mediæ" o "Decretales intermediæ", fue obra de un erudito, el inglés Juan de Wales (de Walesio, Walensis o Galensis). Alrededor de 1216 otro erudito desconocido elaboró la "Compilatio quarta", la cuarta colección, que contenía las decretales del pontificado de Inocencio III, los cuales son de una fecha posterior al 7 de enero de 1210, y los cánones del Cuarto Concilio de Letrán efectuado en 1215. Finalmente, la quinta compilación es, igual que la tercera, un código oficial, compilado por orden del Papa Honorio III (1216-1227) y aprobada por ese Papa en la Bula "Novæ causarum" (1226 ó 1227). En 1230 Gregorio IX le ordenó a su capellán y confesor, el dominico San Raimundo de Peñafort (Pennafort), que elaborara una nueva colección canónica destinada a sustituir las colecciones anteriores. Se promulgó en la Bula "Rex pacificus" del 5 de septiembre de 1234, justificándola en la inconveniencia de recurrir a varias colecciones que contenían decisiones muy diversas y a veces contradictorias, que exhibían en algunos casos lagunas y en otros una extensión tediosa; además, la legislación era incierta sobre varios asuntos. San Raimundo se tomó casi cuatro años en terminar la obra, y siguió en ella el método anterior de las "Quinque compilationes antiquæ". Tomó prestado de ellas el orden del asunto, la división en cinco libros, de los libros en títulos y de los títulos en capítulos. La nueva compilación no llevó ningún título en especial, pero fue llamada "Decretales Gregorii IX" o a veces "Compilatio sexta", es decir, la sexta colección con referencia al "Quinque compilationes antiquæ". También fue llamada "Collectio seu liber extra", es decir, la colección de las leyes no incluidas ("vagantes extra") en el "Decretum" de Graciano. De ahí la costumbre de denotar esta colección con la letra X (es decir, "extra"). Las citas de esta colección se hacen indicando el número del capítulo, el nombre de la obra va como (X), el número del libro y el del título. Usualmente se citan el encabezamiento del título y a veces las primeras palabras del capítulo; por ejemplo, "c. 3, X, III, 23", o "c. Odoardo, X, De solutionibus, III, 23", se refiere al tercer capítulo, que comienza con la palabra Odoardo, en la Decretal de Gregorio IX, libro III, título 23, llamado De solutionibus". Descartamos poner bibliografía al respecto, dada la enorme amplitud del campo, siendo estos datos fácilmente confrontables y ampliables en cualquier tratado de derecho canónico. 
cursu, per plures columnas, in $1.2, t t .{ }^{o} 23, p .^{d a}$ 2. Singular y graçiosamente lo dize Matheo de Afflictis, in rubrica, quae sint regaliae, in usibus feudorum ${ }^{6}$, fol. 159; y Marquardo in libro Contra inimicos Crucis Christi, p. ${ }^{\text {te }}$ 2, cap. 6, nu. ${ }^{\circ} 26$ et 27, fol. 90 et sequentibus et fol. 30, nu. ${ }^{\circ} 10$, col. 1, dize ser esta opinión más común y cathólica y verdadera y más útil a la fee christiana. Albertinus in rubrica De haereticis ${ }^{7}, q .{ }^{e} 8$, p. $^{a}$ concl. $^{e}$, fols. 22 et 23; Navarro in cap. Novit, De iudiciis ${ }^{8}, 3$ notab. Aunque Menchaca, in Quaestionibus illustribus, lib. 1, caps. 20 et 21, fol. 60 cum seq., aviendo referido las opiniones, y que ambas son comunes, tiene lo contrario, y que el papa no tiene ambas potestades eclesiástica spiritual y temporal, sino sola la spiritual eclesiástica; sería nunca acabar referir los que esto tratan, y çierto se confunden los que aquesta opinión postrera tienen, visto que el Alexandro 6 hizo la conçessión de que se trata y donó las jurisdiçiones y dominios de estas tierras y mares, abraçando la dicha opinión de Hostiense que dixe ser más común y cathólica y más provechosa; y es de notar que aquel pontífiçe, demás de aver sido virtuosísimo y de linaje y valeroso, era muy gran letrado y de gran esperiençia, según lo dizen los hystoriadores y la Pontifical, lib. VI, fol. 148. Y aviendo usado de esta opinión y seguídola con deliberaçión del sacro senado de los cardenales, que siempre los pontífiçes proceden de fratrum suorum Consilio, ut in pluribus Decretalibus et Extravagantibus habetur, in c. licet $^{9}$, c. in Genesi ${ }^{10}$, cap. ecclesia $2^{11}$, in fine de electione; licet papa non teneatur se qui consilium cardinalium: glossa in Extravaganti, vas electionis, de censibus ${ }^{12}$, inter communes, fol. 26, in verbo Consilio; Albertinus in c. Quoniam, de haereticis, q. ${ }^{e}$ 10, nu. 12; Simancas, tt. 41, nu. 14, fol. 159; y mejor que todos lo dize Menchaca, lib. 1 quaestionibus illustribus, c. 23 per totum; y después del papa Alexandro 6, los suçessores en la sylla apostólica an revalidado la bula con otras muchas que an concedido, ut supra. No ay que disputar ni dudar deste privilegio: maior enim est auctoritas papae quam sanctorum doctorum, ut inquit Cataldinus de Boncompagnis in tractatu De Potestate Papae, nu. ${ }^{\circ} 89$, in vol. 10 Diversorum Doctorum, fol. 146; et quod observandae sunt leges papae sicut leges dei, in cap. Palam 10, distinct. ${ }^{\text {13 }}$, ubi plura; et S. Thomas, 2.2, q..$^{e} 10$, art. ${ }^{\circ} 12$ in

6. Lib. 2.

7. Decretales, lib. 5, tít. 7.

8. Ibid., lib. 2, tít. 1, c. 13.

9. Decretales, lib. 1 , tít. 6 , c. 6 .

10. Ibid., lib. 1, tít. 6, c. 55 .

11. Ibid., lib. 1, tít. 6, c. 57.

12. Extr. com., lib. 3.

13. Decreto de Graciano, primera parte, dist. 11, c. 9. El Decretum Gratiani o Concordia discordantium canonum, conocido como Decreto de Graciano (y como "Concordancia de las Discordancias de los Cánones", "Armonía de los Cánones Discordantes" o "Concordia de los Cánones Discordantes") es una obra esencial del derecho canónico que, como indica su título, busca conciliar la totalidad de las normas canónicas existentes desde siglos anteriores, muchas de las cuales llegaban a ser opuestas entre sí. Su autor fue el monje jurista Graciano quien elaboró la obra entre 1140 y 1142. La obra, monumental en su extensión, constituye una unificación jurídica esencial, siendo la primera de la colección de seis obras jurídicas canónicas conocida como Corpus Iuris Canonici. El Decreto alcanzó gran difusión, pese a que no fue promulgado oficialmente (aunque, según la tradición medieval, habría sido aprobado por el Papa Eugenio III), no sólo por su indudable utilidad, sino por la autoridad propia de los textos recogidos en la misma: cánones pertenecientes a concilios tanto ecuménicos como locales, europeos, africanos o asiáticos, así como textos de las Sagradas Escrituras, de la Patrística y de algunas fuentes romanas (en su segunda versión). La obra fue posteriormente comentada mediante glosas, destacando en este punto la labor del Papa Alejandro III. 
responsione, ibi ${ }^{14}$; unde magis standum est aucthoritati ecclesiae, etc. Chaseneus, in Cathalogo Gloriae Mundi, fol. 91, col. 2, in te $^{\text {te }}$ 4, consideratione 7, allegat textum in cap. De libellis, 20 distinct. ${ }^{\text {, }}$ ubi glossa inquit quod haereticus convincitur esse, qui non recipit statuta ecclesiae; ad idem est textus in cap. Si ille ${ }^{15}, 50$ dist. $^{e}$ ibi, non solum temerarium, sed etiam periculosum esse non dubito. Con esto concluyo contra lo que podrá replicárseme de lo que dizen el doctor Navarro, in c. novit, de iudiciis, y Covarrubias in regula peccatum, parte $2, \S \S 9$ et 10 , pues ellos mismos acuden ad propagandam catholicam fidem. Assí que valió la concessión, y afirmar lo contrario sería heregía o casi, como lo refiere Gregorio López, in dicta repetitione de bello, posita in d. l. II, col. 3, fol. 79, post medium $^{16}$, in duobus enim ampliatur potestas papae, ratione delicti, scilicet, vel ad bonum et propagationem totius fidei, ut ibi et per Simancas in tit. de papa n. 25 et 26. Victoria etiam in relectione De potestate papae et Concilii, nu. 17, ibi, quia sacrilegum est disputare de potentia papae, in cap. Si quis suadente, in § Committitur, et sequenti 17, q. 4; Fr. Jhoan Frocher, fol. 18. Rursus ibidem inquit Victoria quia profecto hoc esset in turbationem et dissolutionem ecclesiasticae hierarchiae et aucthoritatis, si quilibet posset dicere, papa non potest, de quo pullularunt haereses; est quidem supra omnia iura mundi papa, ut per Chaseneum ubi supra; et inquit Carrerius in tractatu De haereticis, nu. 27, quod contrahitur haeresis oppugnando privilegia Romanae ecclesiae; et nu. se.ti dicit, item contrahitur haeresis contemnendo statuta et mandata ecclesiae et papae, asserendo papam non habere potestatem condendi; tunc enim ut haereticus punitur; allegat textum in cap. Nulli fas est, distinct. $19^{17}$, ibi, sitque alienus a divinis et pontificalibus officiis, qui noluerit praeceptis apostolicis obtemperare; et haereticus est qui dixerit epistolas seu decretales papae nullius esse momenti; ita docet divus Alfonsus de Castro, lib. VI De haeresibus, verbo «Ecclesia», 3 haeresi, fol. 98; Simancas, tt. 24 De ecclesia, nu. 25-26-31-32; textus formalis, in c. Si Romanorum, 19 distinct. ${ }^{18}$, ibi, ut siquis in illa commiserit, noverit sibi veniam denegari.

4. Presupuesta esta verdad de ser validíssima la conçessión, buelvo a la duda prinçipal, y me pareçe, siendo de V. M. como son jurídicamente todas las Yndias y tierras firmes dellas en el universo y los dominios y jurisdiçiones que los moros adondequiera que hazen veneraçión al maldito ympostor Mahoma no pueden habitar, ni V. M. los deve dexar bivir en sus Reynos, ni aun puede, sino expellerlos, por no incurrir en las descomuniones y çensuras de la clementina única De Iudaeis et Sarracenis ${ }^{19}$, adonde el pontífiçe Clemente quinto absoluta y christianíssimamente dispuso, con aprobaçión del conçilio de Viena, que ningún prínçipe christiano cathólico permita bivir ni habitar mahometanos en sus tierras y Reynos adonde tuviere jurisdiçiones y dominios, y manda que sin réplica y en todo caso se cumpla así, con palabras y diçiones taxativas, debaxo de obtestaçiones del juyzio divino, ibi, de terris suis omnino auferant et a suis subditis auferri procurent, inhibendo expresse, ne praefata invocatio seu professio nominis ipsius sacrilegi mahometi publice aut peregrinatio praelibata ab aliquo in eorum existente dominio, audeat attentari de caetero vel quomodolibet substineri, etc. Lo mismo dice la ley 1 , tt. 25, p. $^{\text {da }} 7$, ibi, "pero en las villas de christianos non deven aver los moros mezquitas ni

14. Migne, Pl, III, 102. Jacques-Paul Migne (1800-1975): Patrologiae Latinae Cursus Completus, en dos series (París, 1844-55, 217 vols. en total), con cuatro volúmenes de índices (1862-64, vols. 218-221). Compiló todos los escritos disponibles hasta su época de autores eclesiásticos latinos, desde el más antiguo conocido hasta el Papa Inocencio III (m. 1216).

15. Decreto de Graciano, primera parte, dist. 50, c. 58.

16. Partida 2, tít. 23.

17. Decreto de Graciano, primera parte, dist. 19, c. 5.

18. Ibid., primera parte, dist. 19 , c. 1 .

19. Lib. 5, tít. 2. 
hazer sacrifiçios, etc."; in cap. non invenitur, 23, q.e $4^{20}$, inquit Augustinus: quis enim vestrum non laudat leges ab imperatoribus datas adversus sacrificia paganorum?; in l. 1 et seq. C. De paganis et sacrificiis eorum ${ }^{21}$. No es de maravillar que el papa quite Reynos a moros, pues los puede y suele quitar a Reyes christianos por causas graves, como se quitó por el papa Inocencio 4 el Reyno de Çiçilia al Emperador Friderico in c. Ad apostolicae, De re iudicata, lib. VI ${ }^{22}$, ubi est bona glossa et doctores docent, y por el papa Zacharías el Reyno de Françia al Rey, y se dio a Pipino, padre de Carlo Magno in cap. Alius 15, q.e $6^{23}$, y al rey de Portugal se quitó el reino y se dio a un conde, in c. Grandi, De supplenda negligentia praelatorum ${ }^{24}$, lib. VI; y allí y en otras muchas partes los doctores lo tratan largamente, y también se quitó el Reyno de Navarra en nuestros tiempos y se dio al señor Rey cathólico don Femando, sobre lo qual escrivió un largo tratado el doctor Palaçios Rubios De retentione regni Navarrae, al qual me remito, propter iniustitias et contumelias, ut Eccli., cap. 10 ${ }^{25}$ : Regnum de gente in gentem transfferetur, etc., et Matt. 21. cap. ${ }^{26}$ : auferetur a vobis regnum et dabitur genti facienti fructum eius. En aquella extravagante está una buena glosa y grande y Covarruvias la entiende bien in Regula Peccatum, 2 p.e, § 9, fol. 73; y assí se a de entender lo que dize el maestro Victoria in relectione De potestate Ecclesiae, pag. mihi $76, n u .6$ et 7, que por contemplación de la spiritualidad puede el pontífiçe privar a los Reyes de la temporalidad, ut supra; Gregorio López in lib. I, tit. 1, Partida 2, in glossa En las cosas, et in prologo, in litera f. et $g$. Bien alude el maestro fray Domingo de Soto, De iustitia et iure, lib. $V$, quaest. 3, art. 5, pag. 419, vers. alii sunt infideles. Y una y la primera causa de guerra justa que pone la ley 2, tt. 23, p. da 2, dize ser por acreçentar el pueblo su fee; y sobre esta palabra haze Gregorio López allí la repetiçión; et de Regno Hierusalem, quando donatum fuit Carolo per papam, tradit Bartholus, in lege id, quod apud hostes, ff. 'De legatis, $1^{27}$, et ibi doctores; Oldradus, consil. 268, et cum Bartholo transeunt omnes communiter, ut per Marquardum, c. 6, fol. 30, nu. 10, quod valuit donatio et nihil est honorificentius quam ut rex vel imperator ecclesiae filius esse dicatur, ut per glossam et quae ibi traduntur in Extravaganti 1 Ioannis 22, De iudaeis et sarracenis, fol. 17, in verbo filii nostri. Simancas refert privationes regum factas per papas, in $\mathrm{tt}$. de papa, $n u .^{\circ} 24$, fol. 208. plura regna ablata fuisse per papam a Regibus abutentibus refert Menchaca, Quaestionibus illustibus, lib. I, cap. 8, nu. 20, cum seq. fol. 33, ubi allegat bullam istam de qua agimus, y dize una cosa gravísima, quod ipso iure todo Rey tirano es indigno y privado de su potentado, y a lo menos no le falta más que sentençia declaratoria, y entralle y tomalle el Reyno el christiano Rey cathólico idem, cap. 18, nu. ${ }^{\circ} 10$, y alega muchos doctores y doctrinas para ello, los quales no refiero por escusar prolixidad.

5. Advierto que el caso de mahometanos de que voy tratando es diverso de lo que toca a los otros infieles, que son infieles simpliçiter, de los quales y de los idólatras y que usan contra legem naturae haré tratado aparte.

6. Assí que como de todos los otros sus Reynos, puede y deve V. M. echar y expeller a los moros de todas las Yslas Philipinas del archipiélago y a lo menos subjetarlos y hazerlos

20. Decreto de Graciano, segunda parte, c. 23, q. 4, c. 41.

21. Lib. 1, tít. 11.

22. Sexto de las Decretales, lib. 2, tít. 14, c. 2.

23. Decreto de Graciano, segunda parte, causa 15, q. 6, c. 3.

24. Sexto de las Decretales, lib. 1, tít. 8, c. 2.

25. Vers. 8 .

26. Vers. 43.

27. Lib. 30, tít. 1, 1.9. 
tributarios, debellando los de las Javas y Samatra, Achen, Borney, Mindanao, Xoloc, Malucos, Malaca y de Siam y Patán, Pegu, y otros Reynos en que se adora Mahoma, cuya veneraçión y mala secta traxeron por acá persas, y arabios, y egipcios, y turcos, y aun vinieron moros de Túnez y de Granada, algunas vezes en armadas del Campsón, Soldán que fue del Cayro y Rey de Egipto, como en muchas partes se collige de las historias de Portugal y espeçialmente de la que escrivió en buen latín el obispo de Algarve don Iherónimo Ossorio por mandado de la magestad del señor Rey don Enrique, siendo cardenal, lib. 4, fol. mihi 342, adonde dize que vinieron a la Yndia contra Alonso de Albuquerque, capitán general del glorioso señor Rey don Manuel, abuelo de V. M., emviados del dicho Soldán en una armada veynte y siete navios y galeras, seteçientos mahometanos mamelucos, y trezientos turcos y mill moros de Túnez y de Granada, cuyo general se dezía Solimán, turco de naçión, y embió esta gente a instançia y con promessas que le hizieron de servirle, confederándose con él casi todos los Reyes de la India, que le prometieron gente y muniçiones y grande aliança, año de 1517 años. En efecto, son estos desçendientes y enseñados de los de Meca, Persia y Egipto y sus disçípulos y confederados, y aun podemos dezir que fueron antes súbditos de los Soldanes del Cayro, Reyes de Egipto, pues como escrive el doctor Gonzalo de Illescas en Las historias pontificales, en el lib. 6, y en La vida del papa Paulo $3^{\circ}$, § 5, fol. 161, col. 3, antiguamente los soldanes del Cayro tenían y gozaban la espeçiena y la llevavan destas yslas y de las de Maluco hasta el mar Bermejo, y de allí al Cayro, por una canal de ochenta millas, que Sesostris, antiquíssimo Rey de Egipto, hizo para sólo esto de la espeçieria, y algo se refiere en El libro del Tamorlán, fol. 32. Ninguna duda me queda ni ay para dexar de entender que estos mahometanos sean desçendientes y enseñados disçípulos de los anteçessores egipcios, cuyos alfaquíes y de Arabia y de Meca uvo y ay en los dichos Reynos y yslas; déxase entender todo lo dicho, pues el comerçio que avía de gente en Malaca, y uvo de tiempo inmemorial a esta parte, era de la Yndia toda y Aurea Chersoneso, que es Samatra y Javas y Borneyes y Luzones, que son los de Manila y los de Siam y Patán y Pegu y chinos, bengalas, malabares, guzarates, persas, arabios, lequios, y otras naçiones, según lo refiere Barros en la Década $2^{a}$, lib. 6, cap. 1, fol. 81, y como se juntavan a comerçiar y tratar, se comunicavan en las sectas tanbién.

7. Y no es de maravillar de los egipçios que muestren contra los christianos la enemistad que sus passados tuvieron contra el patriarca Jacob y su pueblo de Ysrrael, y él contra ellos, pues en el cap. $47^{28}$ del Génesis tomó juramento a Joseph, su hijo, hallándose cercano a la muerte, y que tenía ya edad de çiento y cuarenta y siete años, y le mandó que no permitiese enterrar su cuerpo en Egipto, ibi, cumque appropinquare cerneret diem mortis eius, vocavit filium suum Joseph, et dixit ad eum, si inveni gratiam in conspectu tuo, pone manum tuam sub femore meo, et facies mihi misericordiam et veritatem, ut non sepelias me in Aegypto. Este conçeto tuvo el papa Jhoan vigéssimo segundo, en la extravagante Copiosus, De Iudaeis et Sarracenis ${ }^{29}$, que a instancia del infante don Pedro, tutor que fue del señor Rey don Alonso de Castilla, conçedió aquel pontífiçe sus çensuras contra los que llevassen a los moros de Granada y a los de Egipto algunas armas, galeras y vituallas y otras cosas y pertrechos de guerra. Y aunque allí haze la prohibiçión por tiempo de tres años, no se infiere que sea temporal ni para sólo aquel tiempo, como allí lo declara la glosa, mayormente estando prohibido lo mismo en el derecho canónico para siempre, antes de aquella extravagante, in cap. ita quorundam, De Iudaeis et Sarracenis ${ }^{30}$, adonde

\footnotetext{
28. Vers. 29.

29. Extrav. Iohannis XXII, tít. 8, c. único.

30. Decretales, lib. 5, tít. 6, c. 6 .
} 
los doctores largamente escriven, y en espeçial el doctor Azpilcueta Navarro hizo una larga repetiçión; y aora en los motuproprios están renovadas las maldiçiones y çenssuras por el santo padre Gregorio 13, pág. 427 et seq., cap. 6. y el papa Clemente V también prohibió lo mismo contra los mahometanos de Egipto, ibi, in Alexandriam et ad alia loca Sarracenorum terrae Aegypti, etc. He referido esta especialidad de Egipto para verificar la desçendencia y amistad destos moros de las Philipinas, Malucos, Borneyes y los demás dichos.

8. Y de creer es que pues los egipçios tenían la espeçieria y tratavan y señoreavan las yslas, dogmatizarían y enseñarían a los naturales, como los enseñaron y doctrinaron, en la ley de Mahoma, y les pusieron nombres y renombres de moros, como son Abrahemo y Almançor, que era Rey de Tidore, y Abdalá y Raxá Solimán y Alcandora y Mahamut y Mahamet; y Çidiali era granatense y embaxador del rey de Calicut contra los portugueses, y assí ubo y ay otros; y a los que tienen por grandes capitanes los llaman «bassá» o «baxá», y assí llaman al presidente y a los oydores de aquí; y el Rey de Bornev se llama Soltán Lexar, que salió con armada de muchas galeras y artillería y gente, contra el doctor Francisco de Sande ${ }^{31}$, governador de estas yslas, y aviéndole requerido con la paz y amistad mostrando siempre vandera blanca, en efecto començó a tirar cañonazos primero, según pareçe por el proçeso de aquella jornada, el qual yo lo tuve en mi poder para certificar esto, de manera que todos quantos mahometanos ay por este cabo del mundo son enemigos conoçidos, y bien se pareçe en la rebellión del Maluco y Ternate que en tanta neçecidad a puesto a V. M. y a este campo dé Dios victoria a la armada que aora se embió contra aquellos moros. Y en quanto a los de Borney provado está que son los señores tiranos y sus prinçipales de Meca que es la casa y solar conosçido de Mahoma, y son corssarios piratas, et forte les comprehenden el cap. 3 de la bulla de la çena; y tanbién es de creer que los de Egipto, Arabia, y de Meca que vinieron, dirían a los naturales la enemistad capital que tienen contra la yglesia y toda la christiandad. Profetizado estava y está visto, lo que el ángel dixo a Agar esclava de Abrahán que nasçería della un hombre, que después se llamó Ysmael y sus desçendientes y sequaçes se llamaron y llaman impropiamente sarraçenos, del qual dize la Escriptura, Gen., 13 cap. $^{32}$, hic erit fertis homo; manus cius contra omnes, et manus omnium contra eum. En efeto, la profecia salió y sale çierta, pues son capitales enemigos de la christiandad, et omnis qui copulavit amicitiam cum inimico meo est vere inimicus meus, traddit Deçius in 1 . Consilii, § socii mei socius, nu. 3 , ff. de regulis iuris $^{33}$. Excelente decreto es el cap. Si inimicus, 93 distinct. $^{34}$, que refiere un sermón que Sant Pedro, como príncipe de los apóstoles, hizo a los christianos al tiempo que ordenó por succes-

31. Francisco de Sande nació en Cáceres hacia 1540. En 1558 comenzó sus estudios de derecho canónico en Salamanca, concluyéndolos posteriormente en Sevilla. Ya como profesional del derecho, el 18 de junio de 1568, fue nombrado alcalde del crimen en la Audiencia de México y al poco tiempo desempeñó el puesto de fiscal. El 30 de abril de 1572, fue nombrado oidor de la misma Audiencia. Por cédula real de 6 de abril de 1574 se le nombra gobernador y capitán general de Filipinas, tomando posesión de su cargo el 26 de agosto de 1575. En Filipinas fundó la villa de Nueva Cáceres, además de enviar una expedición para intentar la conquista de Borneo. En una carta fechada en 30 de mayo de 1579 se atrevió a solicitar al rey Felipe II el permiso respectivo para iniciar la conquista de las islas Molucas y hasta de China. Quizás por éstos y por otros excesos, en junio de de 1580 se le relevaba del cargo en Filipinas y volvía nuevamente a México para ocupar su antiguo cargo de oidor de la Real Audiencia.

32. Vers. 16 .

33. Lib. 50 , tít. 17, I. $47, \S 1$.

34. Decreto de Graciano, primera parte, dist. 93, c. 1. 
sor suyo a Clemente, y les dixo estas palabras, si inimicus est iste Clemens alicui pro actibus suis pravis, vos expectare nolite, ut ipse vobis dicat; cum ilio nolite amici esse, sed prudenter observare debetis et voluntati eius absque commonitione obsecundare, et avertere vos ab eo, cui ipsum sentitis adversum, nec loqui iis, quibus ipse non loquitur, etc. Gravíssimamente nos enseñó Sant Pedro la enemistad que avemos de tener a todos los que la tienen con el pontífiçe y con la yglesia cathólica, diziendo que no esperemos declaraçión alguna, sino que nos lo tengamos por dicho. El trato que avemos de tener con mahometanos, bien lo significa el redemptor, Ioanis, 12 cap. ${ }^{35}$, ubi ego sum, illic et minister meus erit et mahometanos accipimus sarracenos, mauros, turcas, et ceteros barbaros omnes, qui Mahometem illum impostorem et pseudo prophetam colunt, quorum omnium secta spurcissima est et falsissima; Navarro, in repetitione, cap. Ita quorundam 4, notab. nu. 8 , pag. 32, et num. 9, pag. 36, quod generali nomine dicuntur sarraceni, licet sint turcae, arabes, mauri, egyptii, africani, persae et alii, sicut et omnes in christum credentes christiani dicuntur, allegat glossa in cap. 1, distinct. 22; ita docet episcopus Simancas Contra haereses, tt. 39, adonde quenta la tontería de aquel miserable Mahoma que en su Alcorán dixo que confessava no saber si él y sus sequaçes andavan en camino de salvaçión con la secta; videndus est Albertinus, $q .{ }^{e} 8$, col. 6, in principio, fol. 24, col. 1; archiepiscopi Florentinus, p. ${ }^{e} 3$, cap. 5, fol. 94 . Assí que me pareçe que entran en la cuenta estos moros de las Yslas Philipinas, mayormente que, como está dicho, vienen de Egipto y de Arabia y de Meca, y son parientes, disçípulos y miembros suyos, y cada año dizen que vienen a la Samatra y a Bornéi turcos, y a Ternate, adonde están abra algunos de los vençidos en la famosa batalla naval que dio el señor don Jhoan de Austria. Y a otras islas del Maluco tanbién vienen y suelen venir a predicar la secta, y dar avisos para guerra contra christianos.

9. No pueden dezir los mahometanos que no han tenido notiçia de Jesuchristo, nuestro Redemptor, pues en su Alcorán tienen, y en su secta creen ser verbo de Dios, y aver naçido de la Virgen purísima nuestra señora, y por obra de Espíritu Santo, como lo refieren la glosa y el Cardenal Zabarela in dicta Clementina unica De Iudaeis et Sarracenis, y otros doctores en muchas partes, especialmente el Fortalitíum Fidei, lib. 4, De bello Sarracenorum, in declaratione 2 articuli fidei nostrae, in fine, fol. mihi 176, y el doctor Gonçalo de Yllescas, en la parte primera de la pontifical historia, en la vida del papa Honorio 1, lib. 4, fol. 136; convénçense estos desventurados moros por su mismo Alcorán, pues en quanto confiessan que Jesuchristo es hijo de Nuestra Señora, confiessan que es hombre verdadero, y en dezir que es verbo de dios, confiessan ser dios verdadero, y no lo quieren creer, açerca de lo qual el mismo autor de aquel libro Fortalitium Fidei, en la hoja siguiente $1^{\mathrm{a}}$ primera col. ${ }^{\mathrm{a}}$ refiere una cosa de Mahoma que si sus moros la quisiesen attender fácilmente creerían en la ley christiana, porque haziendo contemplaçión en Nuestra Señora el dicho impostor falso Mahoma dize que le dixo el Arcángel Sant Gabriel, o Maria deus elegit te et decoravit te gratia, et ornavit et praeelegit super omnes mulieres omnium filiorum matres, et posuit te quasi unum medium inter homines et angelos Dei in paradiso deliciarum; et nullus est quem non tetigerit Satan praeter Iesum et Mariam. Por esto y otras cosas que refiere Marquardo en el libro Contra inimicos Crucis Christi, 3 p. $^{e}$, cap. $1^{\circ}, n u .32$, fol. 123 et seq., dize que si los príncipes moros y El gran Turco admitiesen la predicaçión del Evangelio, seria fácil cosa convertirlos a todos; y el nu. 35 cuenta cómo los sarraçenos que visitan el sepulcro de Mahoma no se tienen por purificados si no visitan y hazen tanbién veneraçión al sepulchro de Nuestra Señora la Virgen María, y que si algún judío quiere renegar de la ley vieja y bolverse moro le hazen entre otras cosas que confiese a Jesuchristo, y que le preguntan de esta manera, credis

35. Vers. 26. 
Iesum Christum fuisse flatu dei ex virgine natum et ultimum prophetarum Hebraeorum? y confessado esto queda por mahometano, y pues tan çerca están de esta Real audiencia de Manila, y tan çercanos de creer todos los artículos de la fee visto que confiessan algunos según tengo referido, justo es potentíssimo Señor, que con mucha gente y muchos ministros siervos de dios, seamos socorridos para socorrer las almas de estos miserables moros disçipulos y reçeptadores, ayudadores y creyentes de Mahoma, contra los quales la guerra está abierta como contra enemigos de la iglesia; ut per omnes in dictis locis, Marquardus in $1^{a} p^{\text {te }}{ }^{\text {, cap. }}$ 6, nu. 10, fol. 30; ley $1^{a}, t t .21, p .^{d a} 4$, ibi. La primera es de los que cautiban en tiempo de guerra siendo enemigos de la fee; esto servirá para los cautibos moros en guerra de estas tierras, si son esclavos, conceduntur etiam indulgentiae pugnantibus contra sarracenos, ut ibi per Marquardum, singularis textus est in cap. Dispar 23, quaest. $8^{36}$, docet somnium viri Darii, in vol. 10 Tractatuum diversorum doctorum, fol. 162, col. 3, in cap. 111; et contra Sarracenos indictum est bellum continuum, quia hostes sunt populi Romani, per Ioannem Baptistam in tractatu De arbitris, in vol. 1 Diversorum doctorum, fol. 80, nu. 3, docet Albertinus, in rubrica, q. ${ }^{e} 3$, et q. 4 , conclusione 4 et 5.

10. Y según la dicha Clementina única V. M. no los debe consentir en estos sus Reynos como hombres descomulgados malditos, pues en efecto según está fundado perteneçen a $\mathrm{V}$. M. todos los Reynos y dominios y jurisdiçiones de infieles del universo por la dicha conçesión tan revalidada ut supra, pondéranse las palabras de la dicha Clementina, de que en muchas partes quiso usar el papa Clemente 5 hablando con los Reyes christianos y mandando que no haya sarracenos en sus reinos, ibi, in terris Christianorum, et ibi, universis et singulis principibus catholicis, sub quorum dominio dicti Sarraceni morantur, et ibi, de terris suis omnino auferant et a suis subditis auferri procurent. Y la yglesia cathólica cada día en todas las missas y sacrifiçios que a dios se hazen ora contra moros diciendo, respice in auxilium christianorum et gentes paganorum et haereticorum, quae de sua feritate confidunt; dexterae tuae potentia conterantur. El Cardenal en la misma Clementina, nu. 6. fol. 142, col. 3, pondera la palabra del testo donde dice terris christianorum, y dice, terrae christianorum dicuntur illae, in quibus christiani habent iurisdictionem et dominium, y alega a otros doctores; et iuxta communem usum loquendi, terra dicitur alicuius ratione solius iurisdictionis, in $l$. ut alfenus, ff. de verborum significatione ${ }^{37}$ et $l$. anniculus $^{38}$, et l. pupillus, § territorium ${ }^{39}$, ff. eodem titulo de verborum significatione ultra y demás de lo allí alegado por el Cardenal y otros, pondero yo estas palabras, meum et tuum, suus suum, porque todas éstas significant ius dominii, notant Bartholus in l. quintus, §argento, ff. de auro et argento legatis ${ }^{40}$, fol. 95; Chasseneus in 'Consuetudinibus Burgundiae, fol. 34, nu. 13, col. 3; Tasso in rubrica, ff. De novi operis nuntiatione ${ }^{41}$, nu. 6; Felinus in cap. 1, De sponsalibus, nu. 8, fol. 126; textus in l. Solum, § Meum; et ibi notant doctores, ff. De rei vindicatione ${ }^{42}$, Ioannes de Lecirier De Pri-

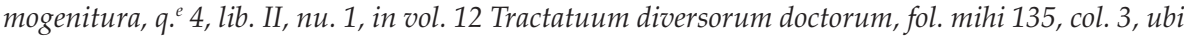
allegat glossam in $\S$ Cum in suo, Instituta, De rerum divisione ${ }^{43}$; Cardinalis in Clementina finali, De

36. Decreto de Graciano, segunda parte, causa 23, q. 8, c. 11.

37. Lib. 50, tít. $16,1.87$.

38. Lib. 50, tít. 16, 1. 132

39. Lib. 50, tít. $16,1,239, \S 8$.

40. Lib. 34, tít. 1, 27, § 2 .

41. Lib. 39, tít. 1 .

42. Lib. 6, tít. 1 .

43. Lib. 2, tít. 1. 
procuratoribus ${ }^{44}$, ego allego decisionem Guidonis Papae, 584; Brecheus in 1. Meorum et tuorum appellatione actiones quoque contineri dicendum est, ff. De verborum significatione ${ }^{45}, n u .8$, pag. 216. Assí que perteneçiendo realmente conforme a lo cathólico que tengo referido los dominios y jurisdiçiones a la casa y corona de Castilla y Portugal me pareçe sin duda que V. M. puede y deve echar de sus tierras y a lo menos compeler los moros a que tributen, y exercer contra ellos, hasta que desistan de su secta, y sean corregidos y no se agravien, quia deus concitai ut a Sara verberetur Agar, et cognoscat se Agar et supponat cervicem. El ángel lo dijo, ecce ancillam et filium eius, in cap. dixit Sara ${ }^{46}$ et in cap. recurrat, 32, q. ${ }^{e} 3 .{ }^{47}$ Sic dixit Augustinus supra Ioannem, cuius verba translata sunt in cap. quando vult Deus ${ }^{48}, 23, q .{ }^{e} 4$, et refert Albertinus in dicta rubrica, in q. ${ }^{e}$, in conclusione 9, fol. 27, ubi allegat Oldradum et Ostiensem.

11. Fatíganse mucho los doctores en disputar si absolutamente los sarraçenos y mahometanos, todos los que hubiere en Reynos de Reyes christianos, pueden ser expellidos dellos y despojados de sus bienes; y unos tienen opinión de que siendo dañosos y no seguros, pueden y deven expellerse y despojarse; y otros tienen opinión de dezir que aunque no sean prejudiçiales, y aunque biban pacíficamente, no an de sustentarse, sino expellerse y despojarse de los bienes; de esto trataron los doctores in cap. Quod super his, De voto; Oldrado, in Consilio 72, fol. 18 et in Consilio 264; Albertinus in rubrica De haereticis, $q .{ }^{e} 7$ et q. ${ }^{e} 8$, donde procede por conclusiones, singularmente fol. $20 \mathrm{cum}$ seq.; allí me remito, que allega a muchos; en quanto a la habitaçión y para expeler los moros o para dexarlos vivir en Reynos de christianos, la ley Christianis, Cod. De paganis et sacrificiis eorum ${ }^{49}$ llanamente disponía que no pudiesen ser expelidos ni despojados los que bibiesen quietamente si no los turbulentos y violentos, $i b i$, ut iudaeis ac paganis quiete degentibus, nihil tentantibus turbulentum legibusque contrarium; et iterum ibi, nam si contra securos fuerint violenti vel eorum bona diripuerint, etc. Lo mismo dice la ley $1^{\mathrm{a}}$, tt. 25, p. $^{\text {da }} 7$, aunque con alguna diferencia, ibi, «pero en las villas de los christianos no deven aver los moros mezquitas, ni fazer sacrifiçios públicamente. E las mezquitas que devían aver antiguamente deven ser del Rey, y puédelas dar él a quien se quisiere; e como quiera que los moros non tengan buena ley, pero mientras bivieren entre los christianos en segurança dellos, non les deven tomar ni robar lo suyo por fuerza, etc». Allí lo tratan los doctores y en los lugares arriba referidos. Esta ley de Partida pareçe aver quedado abrrogada, y la dicha ley Christianis, cap. De paganis, por la pragmática que hicieron los señores Reyes Cathólicos don Femando y doña Isabel quando echaron fuera de sus Reynos a los moros de Granada. Y V. M. tiene ya hecha la ley 4, tt. 2, lib. VIII de la Recopilación, fol. 148 et seq., en que manda expeler a los moros aunque biban sin rebeliones y aunque sean pacíficos, adonde en la segunda plana dize assi, «aunque sean paçíficos y bivan quietamente, es razón que sean expelidos de los pueblos de nuestros Reynos y señoríos, y los menores por los mayores y los unos por los otros sean punidos y castigados; por ende nos, con consejo y parecer, etc». Túvose grandíssimo fundamento en la disposiçión desta ley y aplicarse puede aquí pues alude bien el testimonio que tomó Jesuchristo contra los judíos, cuando les dijo, testimonium estis
44. Lib. 1, tít. 10.
45. Lib. 50, tít. 16, 151.
46. Decreto de Graciano, segunda parte, causa 32, q. 4, c. 3.
47. Ibid., id., causa 32, q. 4, c. 2 .
48. Ibid., id., causa 23, q. 4, c. 39.
49. Lib. 1, tít. 10, 1. 6. 
vobismetipsis, quia filii estis eorum, qui prophetas occiderunt, Matt. cap. $23^{50}$, espeçial cuydado a tenido V. M. de echar fuera de las Yndias a los moriscos, por cédulas y capítulos de cartas y sobrecartas, como parece por el Libro de las Cédulas ${ }^{51}$ de Nueva España, a fojas 160, y en las Leyes de la Contrataçión, fol. 10; y últimamente el año de 1572 después de la guerra de Granada se hizo ley en Madrid para que sean expelidos los de Granada, y después año de 78 escrivió V. M. a la Audiencia de México que todos los moriscos, aunque hubiesen pasado con liçençia se echasen de las Yndias; yo tengo esta carta, digo este capítulo autorizado, y es la ley 16, tt. 26, lib. VIII Recopilationis, singular ley para lo mismo.

12. En aquella ley 4 ay dos cosas que advertir; la una es que se hizo la premática por los señores Reyes Cathólicos año de 1502 años y la conçessión del papa Alexandro sexto quando donó los dominios y jurisdiçiones de infieles a los mismos señores Reyes y al señor Rey don Manuel de Portugal fue dada en Roma año de 1493, nueve años antes de la premática y salida de los moros assí que ya estava hecha la conçessión y bula.

13. La otra advertençia es que aviéndose echado los moros de los Reynos y señoríos que tenía Castilla se les mandó espressamente que no fuessen a los Reynos de Aragón, ni Navarra, ni Catalunia, ni a las partes de Africa, ni a tierras del turco, y se les permitió yr a tierras del Soldán de Egipto que entonces se decía Campsón, y assí fueron allá y él tomó la injuria por suya y escrivió el año de 1505 al sumo pontífiçe Julio II con un embaxador fraile del hábito de Sant Francisco guardián del monesterio del Monte Sión, y la carta contenía en suma que en todo caso no fuessen compelidos los moros de Granada ni los otros de Castilla y Portugal a ser christianos por fuerza por vías directas ni indirectas, echándolos de los Reynos, porque a ningún christiano compelía él a ser moro. Y éstas eran quexas que açerca de los moros tenía, haziéndose protector y defensor dellos, y que assí lo mandase a los señores Reyes Cathólicos y al señor Rey don Manuel, y que no le perturbasen la Yndia ni África, porque si perseveraban en ello, procuraría destruir la christiandad y asolaría el Sancto Sepulchro de Nuestro Redemptor. Esta carta embió el pontífiçe a España y a Portugal; respondieron al papa los dichos señores Reyes como el Soldán mereçía, según lo cuenta bien el obispo Ossorio en la Historia de Portugal, lib. IV, fol. 122 y siguientes; es buena letura. E querido traer este punto aquí, porque viene a concluir y confirmar las enemistades viejas del pueblo bárbaro, que dize la escriptura ser Egipto, contra christianos. Y vistas aquellas respuestas, el dicho Soldán Campsón adereçó armadas contra Alonso de Albuquerque, general de la Yndia, y passaron grandes trances. En efeto, se tiene entendido que por entonces desçendieron por el mar Bermejo y otras partes muchos moros que poblaron y predicaron en Maluco, Borney y Javas y en otras, y en estas Yslas Philipinas, y los pobladores deven de ser los más desçendientes de los granatenses y otros enemigos que de las Españas vinieron desterrados y con capital enemistad y por esto serán más justas las conquistas que se an hecho y hicieren donde a avido y ay mahometanos; y en esto es de notar mucho que el santo arçobispo de Florencia en sus Historiales, parte 1, fol. 125, tt. 6, cap. 3, § 1, dize de Santo Thomás Apóstol, que el mismo Redemptor se le apareçió y lo embió a predicar hazia estas partes, et praedicavit Parthis, Medis, Persis et Brachmanis intravitque orientalem plagam et interna gentium penetravit. Graves palabras son éstas y entiendo yo que los bragmanes son ethiopes y abisinos, gente del Preste Juan, y

50. Vers. 31

51. Vasco de PugA: Provisiones, Cédulas, Instrucciones de su Majestad para gobernación desta Nueva España, México, ed. Pedro Ocharte, 1563. Esta obra de Vasco de Puga (m. 1576) es la primera recopilación de leyes de las Indias. 
oriental plaga es la Yndia oriental, que comiença desde el cabo de Buena Esperanza hasta Malaca y Sumatra. Y en aquellas y estas comarcas será lo que Sant Antonino dize interna gentium penetravit; singularíssima virtud mostró el señor Rey don Manuel en la respuesta que escrivió al papa Julio II contra el Soldán, diziendo que aunque oviese passiones entre los Reyes Christianos, las quales el papa pudiera y deviera remediar y hazerlos que se desocupassen para la liga contra los enemigos comunes que a lo menos él todo quanto tenía y tuviese en esta vida avía de ser para quitarla a todos quantos mahometanos ubiese en el mundo, y que si tentasse el Soldán algún desacato contra el Sancto Sepulchro de Jerusalén que la causa pública de toda la christiandad apartaría las passiones de entre los Reyes Christianos para acudir a la grande injuria de todos y dize el dicho obispo en la Historia, fol. 124, communis enim offensio et contumelia solet animos dissidentes coniungere et stimulis incitare ad poenas de hoste superbissimo repetendas.

14. Quiero inferir (si algo vale mi pareçer) que pues las tierras de Egipto fueron del Romano Imperio como es notorio y los Soldanes de Egipto poblaron y sujetaron las Yslas de la Espeçieria y Malucas ut supra resultará de aquí mayor justificaçión de la guerra contra estos moros, pues el caso en que los doctores no dudan de la justificaçión de la guerra contra ellos es quando se haze contra los que detentan y están usurpando las tierras que algún tiempo fueron del Romano Imperio o fueron de christianos según los doctores dizen y refiere Covarruvias a quien me remito, in regula Peccaturn, De regulis iuris lib. VI, parte 2 , $\$ 9$ et $\S 10$; Gregorio López in relectione De bello, col. 3, post medium ${ }^{52}$. Y en las Historias de los Çéssares y de Garibay y Sant Antonino de Florencia pareçe que el emperador Trajano llegó conquistando y sujetando hasta el fin de la Yndia y Malaca, que era la Aurea Chersoneso y Samatra y entiéndese que llegaron por estas yslas y según era aquel emperador orgulloso todas las devió sujetar pues vino hasta trezientas leguas de aquí. En la ley Mercatores, cod. De comerciis et mercatoribus $^{53}$, paresçe cómo el Imperio Romano partía términos con los persas en tiempo de Theodosio y después, en tiempo del emperador Justiniano, fue sujeta la Persia al imperio christiano, in Authentica De heredibus et Falcidiae ${ }^{54}$, in principio, col. 1. Ibi, quatenus Persa conquiescunt. Y no tuvo mucha razón el doctor Navarro (salva pace tanti viri) de dezir en la Repetiçión del cap. Ita quorundam, pag 40, nu. 13, que en la prohibiçíón del dicho capítulo y censuras no se comprehenden los sarraçenos y mahometanos de estas yslas y Yndias, porque dize que no tratan guerras con los christianos que andamos acá por lo que toca a la religión christiana sino sólo por las tierras. Va poniendo allí razones y fundamentos en este intento los quales no deshazen los que yo arriba tengo dichos y fundados por la Clementina única De ludaeis et Sarracenis y por virtud de la conçessión del sapientíssimo pontífice Alexandro sexto y revalidaçiones de los suçessores lo qual no hallo que aya ponderado ni tratado Navarro en aquella Repetiçión, ni en la del cap. Novit, De iudiciis ni otro doctor alguno los quales adonde los tengo referidos y el obispo de Chiapa ${ }^{55}$ y otros muchos que se quisieron entrometer a tratar de la dicha bula y conçessión fue para lo tocante a los yndios infieles simpliçiter ydólatras y no de estos moros en que yo voy tratando y e tratado en este discurso.

15. Invençible razón pareçe la causa de conquistar moros y sujetarlos y doctrinarlos en la fee, saber llanamente que a Ysmael de quien se precian los mahometanos desçender lo llama la Escritura «onager» (que es bestia) según dice Oldrado, Consilio 72, col. 2, cuyas pa-

52. Part. 2, tít. 23, ley 2.

53. Lib. 4 , tit. $64,1.4$.

54. Lib. 2, tit. 14.

55. Se refiere a Bartolomé de las Casas. 
labras son éstas, et Sarraceni ad litteram vocantur bestiae, quia Ismael, pater eorum, vocatus est a domino onager, dicit Merodius, quia futurum erat, quod qui de genere suo descenderent, omnem bestiarum rabiem supergrederentur ut mansuetarum numeras conteretur ab eis, et licet istae bestiae quoad pastum Petro non videantur commissae, sunt tamen pedibus eius subiectae, quoad dominium et potestatem. Justo es subpeditar y domar las bestias semejantes como Aristóteles dize Politicorum, I, caps. 4 et 5 ibi, et qui nec natura ingenuos habent animos, ut verborum doctrina duci queant. necesse est quasi beluas quasdam sub iugo ponere et legum austeritate coercendos fore; et idem philosophus, Etbicorum, X, dicit, et per hunc modum coacti, recta operantes, virtutum actibus assuefaciendo, tandem in bonos viros evadunt, y assí an de sujetarse y domarse y doctrinarse estos bestiales mahometanos para que vengan a la razón como dize el mismo Aristóteles, Ethicorum, II, ibi, ex eo enim quod multotiens agitur secundum rationem, imprimitur forma rationis in vi appetitiva, quae impressio nihil aliud est quam virtus moralis, y ésta devia ser la justificaçión que tomavan los Romanos para sujetar otras naçiones que ellos dezían ser bárbaros para darles leyes de razón natural y de virtud. Singularmente lo dize y enseña Marquardo, parte 1, cap. 14, fol. 57, adonde funda bien cómo fue líçita cosa y neçessaria conquistar primero que predicar a los yndios de la Nueva España, porque fuera impossible predicar sin primero sujetar. El maestro Victoria, aunque dize que no lo quiere affirmar ser justa guerra contra bárbaros tamquam dementes, también dice, sed nec condemnare audeo, in releetione De Indis ${ }^{56}, n u .18$, pag. 371; et est notandum ibi, dummodo constaret hoc lilis expedire; son para esto tres o quatro decretos admirables, in cap. Schismatici, et seq., 23, q. ${ }^{e} 6^{57}$, adonde Sant Agustín Ad Bonifacium y en lo que escrivió a los Donatistas y a Vicentio; y Sant Gregorio, por grandes prediçaciones, dize la orden que se ha de tener en castigar los malos para que vengan a ser buenos y entre otras cosas que todas son muy dignas de considerar dize una el Decreto primero allí, que se vea cómo forçó el Redenptor a Sant Pablo para que amasse y creyesse que fue çegándolo y derribándolo del caballo y tenerlo atónito sin dexarlo comer, ni bever, ni ver de sus ojos tres días, in actibus apostolorum cap. $9^{58}$. Y dize singularmente el cap. Vides ${ }^{59}$ de la misma causa y cuestión, vides non esse considerandum quod quisque cogitur, sed quale sit illud ad quod cogitur, utrum bonum an malum. Y pues tenemos por fee ser bueno lo que se pretende edificar en aquellas almas perdidas, es gran caso dexarlas perder más tiempo. Colligitur ex magistro Victoria, in relectione De Indis ${ }^{60}$, pag. 371 , cum seq. in vers, alius, titulo posset, usque ad finem Repetitions; muchas cosas y largamente alega Guerrero in Speculo Summorum Pontificum, Imperatorum et Regum, cap. 31, pag. 80, y en el cap. 45 , pag. 140, y en todo su discurso no alega lo más sustancial, que se le olvidaron, la dicha Clementina única, De Iudaeis et Sarracenis, y la dicha ley 4, tt. 2, lib. VIII de la Recopilaçión.

16. Y para fortaleçer más mi pretensión cathólica açerca de la potestad del sumo pontífiçe procederé sumariamente por relaçión. Papa, canonice electus, est Deus in terris; Felino alega largo in cap. Ego Nicholaus, in principio, De iureiurando ${ }^{61}$; et vices Christi gerit in terris, in cap. Ad apostolicae, vers, Nos itaque, De re judicata, lib. $6^{62}$; in cap. Ut nostrum, Ut ecclesiastica beneficia ${ }^{63}$;

\footnotetext{
56. Sec. III.

57. Decreto de Graciano, segunda parte, causa 23, q. 6, c. 1.

58. Vers. 1-2.

59. Decreto de Graciano, segunda parte, causa 23, q. 6, c. 3.

60. Sección III, nóm. 18.

61. Decretales, lib. 2, tít. 14, c. 2.

62. Sexto de las Decretales, lib. 2, tít. 14, c. 2.

63. Decretales, lib. 3, tít. 12, c. 1.
} 
in cap. Quanto, De translatione ${ }^{64}$, et non est purus homo papa, glossa in Extravaganti, ad conditorem, Ioannis 22, fol. 29, in Libro Clementinarum; Speculator in tt. Delegato, § Nunc studendum, nu. 51; et vicem non puri hominis, sed puri Dei gerens in terris. De manera que el sumo pontífiçe, assí como es vicario de Jesuchristo Nuestro Redemptor puro y verdadero hombre lo es de puro y verdadero dios y es confusión ésta notoria de los que tienen la opinión contra Ostiense afirmantes que el Pontífiçe no tiene jurisdiçión en lo temporal y querrán dezir que sólo es vicario de Christo en quanto hombre y no en quanto es verdadero dios y sería yerro notorio pues le conçedió las llaves y absoluçiones y condenaçiones para el çielo y para la tierra. Es famosa extravagante de Bonifacio $8^{a}$, prima inter communes ${ }^{65} \mathrm{fol} .6$, ibi, certe qui in potestate Petri temporalem gladium esse negat, male verbum attendit Domini proferentis: Converte gladium tuum in vaginam. Uterque ergo est in potestate Ecclesiae, spiritualis scilicet gladius et materialis; y en la potestad de la Iglesia se verifica lo que profetizó Jeremías, cap. 1, como la extravagante dice allí, ecce constitui te super gentes et super regna, ut evellas et destruas et disperdas et dissipes, aedifices et plantes; itaque potestas terrena sub spirituali, et inquit Apostolus, 1 Cor., cap. $2^{66}$, spirituals iudicat omnia et ipse a nemine iudicatur; et sic Imperator ab Ecclesia Romana imperium tenet, in vol. 8 Tractatuum diversorum doctorum, fol. 9, num. 2; quia Ecclesia Romana est uxor Iesu Christi, in cap. Sicut, 21, q. ${ }^{2}{ }^{67}$, ut inquit Petrus de Monte in Monarchia Conciliorum, in vol. 10 Tractatuum diversorum doctorum, fol mihi 98, col.8, nu. 10; habetque iura terreni ac caelestis imperii, et idem est consistorium Papae et Dei, ut per Ostiensem in cap. Quanto, De translatione praelatorum; Veroyum in cap. 1, De constitutionibus ${ }^{68}, n u .18$, et in rubrica De officio delegati ${ }^{69}, n u .10$, fol. 3. Finalmente dice estas palabras el cap. Cuncta per mundum, 9, q. ${ }^{e} 3^{70}$, cuncta per mundum novit Ecclesia, quod sacrosancta Romana Ecclesia ius omnibus habeat iudicandi, nec cuiquam de eius liceat iudicare iudicio. Si quidem ad illam de qualibet mundi parte appellandum est, ab illa autem nemo est appellare permissus; bien lo declaran las leyes de Partida, ley 4, tt. 5, p. ${ }^{\text {da }} 1^{\text {a }}$, ibi, «onde por todas estas razones debe el apostólico ser mucho honrrado e guardado como aquél que es padre de las almas y señor mantenedor de la fee. Y por esto todos los christianos del mundo quando vienen a él bésanle el pie, onde qualquiera que dixese afirmando como quien lo cree, que el papa non ha estos poderes que avemos dicho aquí, o que non es cabeça de Sancta Iglesia, deve aver tal pena por ello como hereje conoçido». Dize lo mismo por palabras graves la ley 8 del mismo tt. y p. ${ }^{\text {da }}$, ibi.: «honrrando los christianos al apostólico, honrran a Jesuchristo, cuyo vicario es. Otrosí honrran a todos los apóstoles, y señaladamente a Sant Pedro, que fue el mayor dellos, de que tiene lugar, y honrran a toda la christiandad, cuya cabeza es como ordenador y mantenedor de la fee». Bien a propósito viene el cap. 2 de la bula de la Çena del Señor, adonde el pontífiçe Gregorio 13 en los Motuproprios pag. 428, descomulga a los que apelaren para el futuro conçilio de manera que no hay superior en el mundo y aquella palabra del Redemptor, Ioan., cap. $18^{71}$, mitte gladium tuum in vaginam; et Matt., $26^{72}$ : Converte gladium in locum

64. Ibid., lib. 1, tít. 7, c. 3 .

65. Es la que constituye el c. 1 del tít. "De maioritate et oboedentia" de las Extravagantes comunes.

66. Vers. 15.

67. Decreto de Graciano, segunda parte, causa 21, q. 3, c. 3.

68. Decretales, lib. 1, tít. 2.

69. Ibid., lib. 1, tít. 30.

70. Decreto de Graciano, segunda parte, causa 9, q. 3, c. 17.

71. Vers. 11.

72. Vers. 52. 
suum, se deve entender según y como dixe arriba que significan ser proprio el cuchillo temporal de Sant Pedro tanbién como el spiritual, por decir gladium tuum, entendiendo verbum tuum praesuponere dominium ecclesiae, ut supra, et ex divina institutione, non equidem humanis constitutionibus, obtinuit primatum Romanus Pontifex, ut pulchre docet praeceptor meus Covarruvias in lib. XV Resolutionum, cap. 14, nu. 10 et seq., fol. 25, ubi probat haereticum esse contrarium asserere.

17. Visto esto queda llano que no se puede poner en disputa nadie si tuvo o no tuvo el pontífiçe facultad de hazer la conçessión a los señores Reyes Cathólicos y pues él dio los dominios y jurisdiçiones de los Reynos, yslas, tierras firmes de gentes bárbaras, y después ut supra an rrevalidado esto los papas suçesores, mal se deve sentir en los cuerpos y almas de los que tuvieren o quisieren sustentar que no se pudo hazer la conçessión. Y contra moros yo tengo por sin duda mi pareçer açerca de lo temporal, tanbién como de lo spiritual, y aun contra ydólatras sacrificadores de hombres y perpetradores de otras abominaçiones y tiranías. Pero en caso que oviese de valer algo la opinión contraría, sería en simpliciter infieles; y replicando sobre la opinión de Ostiense que como tengo dicho es la más común y más provechosa a la fee de dezir que el papa tiene también la potestad temporal entre otras causas dize que le pareçe a él, quod in adventu Christi omnis honor et omnis principatus et omne dominium et iurisdictio de iure et ex iusta causa, et per illum qui supremam manum habet nec errare potest, omni infideli subtracta fuerit, et ad Christianos translata; et quod iustis causis hoc evenerit probatur Eccli., cap. 10, y por aquella conjunción admirable de entrambas naturalezas divina y humana. El de Chiapa afirma que esta razón es herética y que habían de quemar bivo al que la tuviere afirmativamente. Cosa es çierto de considerar una palabra tan rezia, pues no todo el fundamento de Ostiense y de los graves y doctísimos hombres sus sequaces se funda en sólo lo tocante a aver perdido los dominios los infieles per adventum Christi, sino también en otras razones y decretos, como en el discurso ellos mismos ponderaron. Pero bolviendo yo ahora por Ostiense y su opinión común, muy llano está el cap. Si de rebus, 23, q.e $7^{73}$, ibi, ad omnes iniquos et impíos illa vox Domini valet: Auferetur a vobis regnum et dabitur genti facienti iustitiam; an frustra scriptum est: labores iniustorum pii edent? Es decreto famoso, incluso in corpore iuris y pruébase en toda aquella causa y cuestión, 23 , q. ${ }^{\mathrm{e}} 7$. Y no hace poco al caso lo que Paulo Orossio dize y está referido por el historiador de La Pontifical, lib. 1, fol. 10, que el día de la natividad del Redemptor aviendo naçido en Betlén dixo en Roma y mandó aquel emperador Augusto Çessar por edicto universal y vando público que de aquel día en adelante nadie lo llamase a él Señor, pronosticando que avía ya naçido en el mundo el Señor de todos; cosa de grande consideraçión es un edicto del que se llamava emperador del mundo, y estando en Roma mill leguas de Betlén se rindió llanamente; bien le agradeçió y le esperó Dios, para que le conoçiesse y fuese christiano por aquel reconocimiento, pues le dexó ser Emperador çinquenta y seis años y ningún Emperador a llegado a tanto tiempo de imperio después de él, según la historia pontifical, lib, 6, fol. 148, col. 4, adonde dize que tan poco a llegado ningún pontífiçe a los años del pontificado de Sant Pedro, y que el emperador Federico tercero, asçendiente de V. M., imperó çinquenta y tres años. Y si Adán solo que era puro hombre como el dicho obispo dize tuvo estos dominios y jurisdiçiones del universo, con mayor razón perteneçen a su Criador, el segundo Adán, que así lo llama Sant Pablo, 1 Cor., cap. 15, a Jesuchristo, siendo hombre y Dios, y Dios y hombre, por cuyo naçimiento tuvo exordio el mundo, y por su muerte quedó destruida y muerta la muerte, y por su rresurrectión tomó

73. Decreto de Graciano, segunda parte, causa 23, q. 7, c. 2. 
principio la vida in cap. Quot die, distinct. $75^{74}$. Y así lo canta la Iglesia: "Mortem nostram moriendo destruxit et vitam resurgendo reparavit." Todos los sanctos hystoriadores lo dizen, y el Archiepiscopo Florentino, parte 1, tit. 4, cap. 1, fol. 59, col. 1, et alibi saepe. Profetizado estava por David, Ps. 23 $3^{75}$ : Attollite portas principes vestras, et elevamini, portae aeternales; et introibit rex gloriae. $\mathrm{Y}$ assí se deve entender que las puertas que el demonio tenía çerradas con sus embaymientos y abominaçiones y homiçidios se abrieron con la venida del hijo de dios; y en la vigilia del día de Navidad dize la iglesia, delebitur iniquitas terrae. Y el día dize, magnificatus est rex pacificus super omnes reges universae terrae ${ }^{76}$. Y aora se deven abrir las puertas de los tiranos mahometanos y visitarles V. M. como Señor y Rey de todos los hombres y mantenedor del mantenedor de la fee. Gran vergüença es de los que contradizen las conquistas contra moros, y sin lo dicho basta y sobra, que con diez máximas o reglas de Mahoma se haze adversario y enemigo capital insultando el nombre christiano y diziendo contra la conçepción y contra la divinidad de Christo, y contra la muerte y passión, y contra la dignidad de la Sanctíssima Trinidad, y contra el baptismo de nuestra salvaçión, y otras blasfemias increíbles como refieren los historiadores y el Fortalitium Fidei, fol. 187, col. 2, que son injurias comunes de la yglesia cathólica y conviene castigarlas. Estoy por dezir y digo y afirmo que sin la dicha bula, y aunque no se oviera hecho esta conçessión para la casa de Castilla, pudiera V. M. christianíssimamente enviar por todo el mundo a la predicaçión y conversión de estos infieles y paganos, y compadeçiéndose de ellos, alçar las fuerças y librarlos de las tiranías del demonio y de sus malaventurados tiranos Reyes, y defender los oprimidos y darles lumbre de fee christiana, que ésta es la más propria virtud de los Reyes Cathólicos; libertar de los calumniantes a los que poco pueden y saben, y obra piadosíssima, por lo que famosamente dixo el doctor Azpilcueta Navarro en su larga Repetiçión del cap. Non in inferenda, 23, q. ${ }^{e}{ }^{77}$, non in inferencia sed in depellenda iniuria lex virtutis est. Qui enim non repellit a socio iniuriam, si potest, tam est in vitio, quam ille qui facit. A él me remito y a una ley real que él no alega, in lib. III, tit. 16, Partida 2, ibi, «e por ende a tal fecho como éste, de que tanto mal podía venir, todos son tenudos de venir luego a tollerlo, bien ansí como farían al fuego que ençendiese la villa o las casas en que morassen». Bien alude lo que el maestro Victoria trata De Indis Insulanis, nu. $9^{78}$, pag. 362 et nu. 18, pag. 371, et seq., y mejor en el nu. 15, pag. 368, y los demás que está dicho trataron de los infieles, y quánto más avría lugar contra moros, ut supra et infra.

18. Convénçense los de la opinión contraria pues por librar del demonio y de los pecados al género humano, vino el Redemptor al mundo, y pudo muy cathólicamente el pontífiçe hazer a V. M. y suçessores tutor y corregidor perpetuo de todos los bárbaros, y enseñador de la fee, como quando se dan tutores a huérfanos tiranizados, ignorantes o furiosos locos (ff. et C. De curatore furiosi $)^{79}$, mayormente dándoles maestros y predicadores, y audiençias reales y governadores que a los tales perdidos y subpeditados del demonio los induzgan y puedan apremiar, que assistan a dios y lo conozcan y a los malos y tiranos Reyes destruirlos por el amançebamiento que tienen con el demonio y con aquel onagier maldito hereje Mahoma.

74. Decreto de Graciano, primera parte, dist. 75, c. 5.

75. 24 en la Vulgata, vers. 7.

76. Nota marginal al texto: [Y ansí lo declara el mismo loan. cap. 16., ibi, quia princeps mundi huitis iam iudicutus est].

77. Decreto de Graciano, segunda parte, causa 23, q. 3, c. 7.

78. Sección III.

79. Dig., lib. 27, tít. 10. Cód., lib. 5, tít. 70. 
19. V. M. tiene tan por suyos todos estos Reynos y los que están por descubrir, que en las instruçiones dadas con acuerdo y deliberaçión, consulta y Resoluçión de sus consejos, está mandado muchos tiempos a, que los descubridores, en qualesquiera partes que llegaren, tomen luego la possessión de la tierra y provinçias con la solemnidad de possessión que el derecho requiere, y traygan fe y testimonio dello en pública forma. En el capítulo 13 de la instruçión ordinaria $^{80}$, y açerca de las poblaçiones que se an de hazer, está mandado en el Cap. 136 que si los naturales se pusiesen en defender los edifiçios, puedan los pobladores hazerles tanto daño quanto sea menester para defensa de la poblaçión y para que no se estorve, y sólo esto bastava para tapar las bocas a las solturas de los que atrevidamente quisieron poner escrúpulo en las bulas de la conçessión del papa Alexandro 6 y suçessores, y el obispo de Chiapa quam plura scripssit, quae conscientiae et famae suae consultius fuerat illa tacuisse, aunque algunas cosas tocó bien, pero con muy demasiadas exageraçiones y superlativos, innitens prudentiae suae contra doctrinam Salomonis, fili mi, habe fiduciam in domino, ne innitaris prudentiae tuae, ne sis sapiens apud temetipsum, in cap. ne innitaris; de constitutionibus ${ }^{81}$, ibi, prudentiae suae innititur, qui ea quae sibi agenda videntur, patrum decretis praeponit, son palabras graves de Sant Jherónimo, como allí lo dicen la glosa y doctores, de manera que el dicho de Chiapa ubiera de aver visto y entendido los decretos que yo tengo alegados, para no hablar tan osadamente.

20. Quiero dexar aparte las causas de la guerra de los yndios simplemente gentiles, en lo qual harto escrivieron Victoria y Greg. ${ }^{\circ}$ López y Marquardo y Covarruvias y otros, ubi supra, que ponen muchas causas justas como quando no admiten la predicaçión; y quando nos hazen inquietud y guerra sin offenderlos, y nos defendemos dellos, pone çinco causas de guerra justa Covarruvias, ubi supra, in Regula peccatum, fol. 66; fray Alonso de Castro, diez, De iusta haereticorum punitione, fol 127, lib. 2, cap. 14; Matheo de Afflictis pone 17 causas, in tt. Hic finitur lex, in cap. Domino guerram, in usibus feudorum, fol. 54. Lucas de Pena in 1. 2 C. De apparitoribus $^{82}, 1^{\mathrm{a}}$ col., lib. 12, pone trece causas; también lo declara el padre fray Johan Frocher en su itinerario cathólico ${ }^{83}$, cap. 6, De licita evangelizantium defensione, fol. 5 et seq. Y V. M. tiene permitido y ordenado lo que se deve hazer en el dicho capto. 136 y en otros de las instruçiones que se mandan dar a los descubridores y pobladores de tierras nuevamente halladas, y que se hallaren.

21. Pero en ninguna ordenança ni capítulo de las dichas instruçiones de descubrimientos y conquistas, poblaçiones y pacifiçaciones de las Yndias nunca e visto, aunque e tenido curiosidad, que aya tratádose de la guerra contra mahometanos de estas partes, de lo qual naçió que yo tomase este trabajo de escribir açerca della y advertir a V. M. y para que se nos enbíe instruçión y aviso de la orden que se tendrá en lo que se paçificare, porque en lo que está paçificado, ya no ay en las Philipinas hombre que ose adorar públicamente a Mahoma; que plugo a dios de atajar la pestilençia que començava quando vinieron españoles aquí, y no embargante que los llaman en Manila y toda esta ysla de Luzón, moros, no lo eran sino pocos, y los más son ydólatras simples, y se an quedado con este renombre de moros;

80. Se refiere a las Ordenanzas de Felipe II sobre descubrimiento, nueva población y pacificación de las Indias promulgadas en 13 de julio de 1573. Cfr. su texto en Francisco Morales PAdrón: Teoría y leyes de la conquista, Madrid, Ediciones Cultura Hispánica del Centro Iberoamericano de Cooperación, 1979, pp. 489-518.

81. Decretales, $\mathrm{Hb} .1$, tít. 2 , c. 4 .

82. Tít. 53 (52).

83. Prima pars. 
lo de que se pretende saber instruçión aora es para los de Maluco y Borney, Mindanao, Xoloc y Siam y Patán y otros Reynos, en que están edificados mahometanos, y los de Borney suelen ser cossarios y venir aquí a prender hombres y captivarlos y contratarlos allá.

22. Una cosa quiero advertir açerca de este tratado y es muy essençial y con ella se justifica quanto tengo dicho, que en la Yndia predicó el apóstol Sancto Thomé, y en Goa se halló en unos çimientos de una casa un cruçifixo de metal, que devió ponerlo allí, y avía muchos christianos cuando portugueses fueron, y se sabe que por sus manos el apóstol hizo muchas casas, y convirtió gentes, y se halló una donaçión que un Rey hizo escripta en una pasta de metal en letra canarina, que virtualmente decía: "En nombre de dios, Criador de todos los tres mundos, çielo, y tierra, y luna, y estrellas. El qual por amor de su pueblo le plugo venir a tornar carne a este mundo, etc.", según dize Barrios en la segunda Década, lib. 5, cap. $1^{\circ}$. Y en la çiudad de Cranganor de la Yndia, çerca de Cochimo, se hallaron muchos christianos de los de Santo Thomás, con templos y yglesias christianas, de quien cuenta el obispo de Algarve Ossorio muchas particularidades, desde la hoja 119 hasta el fin del libro $3^{\circ}$ y por esto y por la inquietud que causavan los moros les mandó hazer guerra abierta el señor Rey don Manuel, como refiere el obispo, lib. 2, fol. 65, y en lib. 4, fol. 124, col. 1. Están llenas las historias de guerras de moros de la Yndia contra christianos, y en la ysla Zocotora se hallaron muchos christianos por Albuquerque y Acuña año de 7, que tenían saçerdotes y pagaban diezmos, como dice el obispo Ossorio, lib. 5, fol. 164, que estavan tiranizados de mahometanos y los libraron.

23. Aquí se ha tratado por el obispo don frai Domingo de Salazar ${ }^{84}$ contra los conquistadores en muchas jornadas que an hecho en estas yslas y se compelen y an compelido a desembolsar las restituçiones de las cosas que tomaron en cada lugar, por dezir que fueron robadas, y en esto a usádose con ellos de rrigor, en no los querer confesar ni absolver, si no restituyen, y compélense los que tienen por los que no tienen in solidum, como mancomunados, sin aver partes que pidan, y sin preçeder contradictorio juizio, y sin saber espeçialmente quién y cuántos y quáles son los damnificados, ni los a quien se a de restituir, ni si son moros o simples infieles idólatras, y sin estar juzgado haver sido líçitas o con causas justas las guerras o reecuentros, y sin hazerse distinçión alguna de que las cosas tomadas a los naturales fuessen para comer y sustentarse, o también para robar illíçitamente; buena es la dificultad y tiene todos los miembros y distinçiones que digo, y porque todo ello a ydo en confuso y podrá venirse a tratar en esta Real Audiençia, quiero dexarlo y no manifestar mi voto.

24. Dice Sant Antonino que fue baptizado Mahoma, y lo era su preçeptor; la Historia Pontifical, lib. 4, fols. 135 y 136, dize que Sergio fue maestro de Mahoma y lo baptizó y tuvo las herejías de Arrio y Manicheos y Sabelio e Unomio, Maçedonio y Çerdón. Y en tiempo del admirable doctor Sant Ysidro arçobispo de Sevilla, fue disimulado Mahoma a Córdova y començó a predicar su secta, diziendo que Jesuchristo aunque avía naçido de la virgen María y por obra de Spíritu Sancto, que no era dios ni avía muerto. Embiólo a prender el sancto arçobispo, y huyose en África, y allí predicó y dogmatizó los africanos, de donde an venido tantos trabajos y

84. Sobre la personalidad y escritos del obispo Domingo de Salazar escribieron en su introducción L. HANKE; A. MiLlares: Cuerpo de documentos, op. cit., pp. XXXV-LI, publicando en el apéndice documental tanto el "Tratado del título que los reyes de España tienen para ser señores de las Indias" (Madrid, 1593, n VI, pp. 185-192) al que se está refiriendo en su carta Melchor de Ávalos, como su otro "Tratado en que se determina lo que se ha de tener acerca de llevar tributos a los infieles de las Islas Filipinas, hecho por Fray Domingo de Salazar, de la Orden de Santo Domingo, y obispo de dichas islas" (c. 1593, $\mathrm{n}^{\circ} \mathrm{V}$, pp. 117-184). 
persecuçiones a la yglesia cathólica, como lo refiere el Fortalitium Fidei fol. 166. Y pues aquel maldito impostor fue a contaminar las Españas y las tierras christianas, y lo dize la Historia Pontifical, lib. IV, fol. 151, y que fueron causa estas morismas del mayor mal que jamás el género humano a reçibido; porque si bien discurrimos en el negoçio, hallaremos que de aquí an naçido todas las guerras y males que a avido en el mundo en poco menos de mill años, y de aquí tuvo prinçipio la perdiçión de la mayor parte de la tierra, y ésta fue causa de que la república christiana, que estava entonçes desparzida por todo el oriente en África y Egipto y por el mar mayor y casi en todo lo poblado del mundo, se aya venido a arrinconar, y de aquí naçieron todos los males que nuestra España a padesçido del dicho tiempo a esta parte. Va contando allí el doctor Yllescas muchas y grandes calamidades de la christiandad, y pues tomaron y ocuparon sus moros las tierras y mares de christianos, justo es desarraygar todas sus raízes ut supra que vienen desde el año 615, según Sancto Thomás Contra gentiles, libro $1^{\circ}$, caplo. 6, y según otros muchos que alega Rojas, De haereticis, $1^{\text {a }}$ pte., in principio, nu. ${ }^{\circ} 14$, pag. 7.

25. No es advertençia para dexar de dezir, pues Mahoma fue baptizado, según dizen los historiadores, y tuvo las herejías arriba dichas, que en efeto fue hereje formalmente y dogmatizador y mantenedor de herejías, aviendo sido christiano, ut in $1.1^{a}$, tt. 3, lib. 8 Recopilationis, rub. 26, pda. 7, per Covarruvias, lib. 3 Resolutionum, cap. $1^{\circ}$, nu. 2 et ibi allegat plures; et plura Castro, De iusta haereticorum punitione, lib $1^{\circ}$, cap. $1^{\circ}$ et 7 , fol. 25 et seq.; episcopus Simancas, tt. 31, De haereticis, nu. 4, fol. 139 et seq.; et alibi saepe doctores. Viene bien la doctrina de Sant Jherónimo, canonizada in cap. Resecandae sunt, $24, q .{ }^{e} 3^{85}$, Resecandae sunt, inquit textus, putridae carnes et scabiosa ovis a caulis repellenda, ne tota domus massa, corpus et pecora ardeant, corrumpantur, putrescant et intereant. Arius in Alexandria una scintilla fuit, sed quoniam non statim oppressus est, per totum orbem eius flamma populata est. Lo mismo se prueba en todos los decretos de aquella causa y cuestión. Bien es verdad quod non sunt haeretici qui non sua audacia sed aliena seducuntur in errores, ut in cap. Dixit Apostolus ${ }^{86}$, eadem causa et quaestione, y por esto los sequaçes enseñados de Mahoma, no siendo baptizados, no serán herejes formalmente, pero sonlo largo modo, ut per Gundisalvum de Villadiego, in tractatu De haereticis, $1^{a} q .{ }^{e} 1$, in 4 vol. Diversorum doctorum, fol. 80; Paulus Grilandus in eodem 4 vol., fol. 75, vers. 2 Quaero. Y assí se entiende que no todos los creyentes y defensores serán herejes formados, sino largo modo et improprie, quando no son baptizados, ut per doctores omnes ad quos me refero, y éstos que como digo no son baptizados, que tienen y mantienen herejías y opiniones mahometanas, que virtualmente todo el Alcorán está lleno de herejías de Arrio y de los otros referidos, y son herejes largo modo et improprie, deven ser punidos y castigados por el brazo real seglar, ut inquit Simancas, tt. 31 De haereticis, nu. 4, fol. 140, col. 1, ibi, nam si baptizatus non esset, a iudice saeculari puniri deberet; ad eum me remitto et ad ibi relatos doctores porque todos los infieles y judíos y moros, adonde estuvieren, son del fuero y jurisdiçión secular y no eclesiástico, quia constitutionibus canonum non ligantur, ut refert Anania in rubrica De Iudaeis et Sarracenis, nu. 9, et doctores in Clementina 1, eodem tt. et in cap. Quod super his, ubi Abbas, nu. 14, De voto; Marquardus singulariter in parte 2, cap. 2, nu. 3, fol. 62 et fol. 63 . Y todo esto viene bien con lo que yo arriba tengo dicho que estos moros de por acá, aunque no sean baptizados, deven ser castigadas de V. M. sus iniquidades y blasphemias y heregías formadíssimas que de per se lo son, aunque los moros no se digan herejes formalmente por no ser baptizados, en lo qual, como dicho tengo, el doctor Covarruvias y Castro y Simancas lo enseñan bien et alibi dicam.

85. Decreto de Graciano, segunda parte, causa 24, q. 3, c. 16.

86. Ibid., id., c. 29. 
26. Aquí se puede tratar del entendimiento de una cédula de V. M. escripta al adelantado Miguel López de Legazpi, cuyas palabras son éstas: “También se nos a pedido por vuestra parte, que atento a que ay en essa tierra yslas de moros y ellos vienen y tratan y contratan, los quales impiden la predicaçión del Sancto Evangelio y os inquietan, os damos liçençia para hazer a los tales moros esclavos y tomarles sus haziendas, y estaréis advertidos que si los tales moros son de su naçión y naturaleza moros, y vinieren a dogmatizar su secta mahomética o hazer guerra a vosotros o a los yndios que están a nos sujetos y a vuestro Real servicio, los podréis hazer esclavos; mas a los que fueren yndios y ovieren tomado la secta de Mahoma, no los haréis esclavos por ninguna vía ni manera que sea, sino procuraréis de los convertir y persuadir por liçitos y buenos modos a nuestra sancta fee cathólica".

27. Una máxima haze esta çédula, y es de mandarse hazer esclavos los moros que vinieren a estas yslas a dogmatizar y predicar la secta de Mahoma y a los que impidieren la predicación de nuestra fee, y aora buelvo yo a suplicar a V. M. que mande consultar lo que tengo dicho, juntamente con la dicha çédula o capítulo de carta, para que tengamos acá resolución. No tengo de passar sin tocar la tacha que imponen aquí algunos al doctor Sande, diziendo que tuvo gran culpa en quemar la mezquita de Mahoma en Borney, porque dizen ser aquel Rey paçifico; a mí me pareçe por lo dicho y por lo que diré adelante, que si no la quemara, cayera Sande en mal caso; pruévase por lo que dize frai Alonso de Castro, lib. 2, De iusta haereticorum punitione, cap. 14, fol. 126, col. 4, et seq., ex cap. 12 Deuteronio ${ }^{87}$, Disipase aras eorum, et confringite statuas; lucos igne comburite, et idola, comminuite; disperdite nomina illorum de locis illis. Sobre lo qual la glosa ordinaria pone la causa y es ut memoria et idolatriae prorsus tollantur, et sic tanta Dei iniuria in populo suo evitetur. Assí que en aquella parte de Bornéi, conveniente cosa fue quemar y assolar la mezquita, no embargante que de derecho y por ley primera, tt. 25, pda. 7, las mezquitas que los moros solían tener antiguamente eran del Rey christiano, en cuya tierra se permitían y toleraban habitar; aluden la ley $1^{\mathrm{a}}$ y la ley nemo ${ }^{88} \mathrm{y}$ la ley omnia ${ }^{89}$, C. De paganis et sacrificiis et templis eorum. Pero en Borney fue aquello cosa neçessaria por no se aver podido quedar el doctor Sande allí, ni dexar presidio, a causa de que algunos capitanes y soldados dexaron a su general en aquella çiudad, que tan virtuosamente y tan en serviçio de dios avían conquistado, y se bolvieron a Manila, y se quedó el Doctor Sande, que aunque los permitió bolver, fue para provarles si la gana que tenían de venirse era çierta, y assí los despidió desgraçiadamente, confiándose en que dios le daría salud, y como sobrevinieron enfermedades al resto que le quedava de gente, ubo de venirse a su pesar, porque aquel Reyno es importante mucho, y escala para todas las navegaçiones de por acá de la Yndia y Malaca para Malucos, y de acá para allá y para Siam y Patán y Javas, y para yr a España sin rodear. Y llamar los frailes al moro de Borney Rey paçífico, rezio caso es y áspera cosa, siendo Rey mahometano doctrinado en la capital enemistad del nombre christiano. El prohemio de las Decretales dice, Rex pacificus pia dispositione disposuit sibi subditos fore pudicos, pacificos et modestos, y nada desto tienen los moros de Borney, ni otros de otras partes que guardan bien la orden de hurtar y robar, porque Mahoma y sus prínçipes no les dan otros gajes ni estipendios, sino lo que robaren, según refieren Angelo de Perusio, in lib. 2, § Cum in eadem, ff. Ad legem Rhodiam de iactu ${ }^{90}$; Alciato in lib. I De verborum significatione, in fi-

\footnotetext{
87. Vers. 8.

88. Lib. X, tít. $11,1.8$.

89. Ibid., id., 1. 5.

90. Lib. 14, tit. 2, 1. 2, § 2 .
} 
nalibus verbis. Y fue el séptimo preçepto del Alcorán de Mahoma que todos puedan robar y cautivar y matar, según lo refiere el Fortalitium Fidei, fol. 184, col. prima.

28. Después de lo que está dicho, por principio de este año de 85, aconteçió hazer el provisor de aquí una informaçión, la qual yo e visto, contra don Agustín Alcándora governador de Tondo, y don Gerónimo Bassa y Juan Bassa y otros sus hermanos y parientes baptizados del pueblo de Tondo, que es el río en medio desta çiudad, un quarto de legua della, los quales aviendo muerto su madre Bine en la secta de Mahoma, la enterraron a su usança y según como estavan y están enseñados de los alfaquíes que antes de aora venían a dogmatizar de Bomei, a los quales llamaban Siac ${ }^{91}$, y para enterrarla tomaron algunos ritos de la infidelidad y ydolatría, y se fueron a una aldea, y en la plaça con mucha pompa hizieron el entierro con el túmulo de vara y media de alto del suelo, y la ungeron y çahumaron diziendo alatala ${ }^{92}$ y la pusieron la tanda tanda, que ellos dizen ser unos palos muy bien labrados como a manera de clavos largos de una terçia, el uno junto a los pies y el otro junto a la cabeça, con protesta de que Mahoma avía de llevar a la mala vieja en camino de salvaçión, y la faxaron y enbolvieron en limpias sávanas, y la pusieron una tabla ençima para que no le cayesse polvo ni tierra; están pressos los denlinquentes por el eclesiástico, y estamos a la mira presidente y oydores para suplir en el castigo lo que convenga, por ser christianos baptizados los consortes aunque la vieja no lo era; dizen los testigos que se halló presente un moro de Borney. Enviarse a desto relaçión de lo proçesado, para que en el consejo se vea.

29. El doctor Francisco de Sande, siendo governador, hizo proçesos y justiçia contra los dichos alfaquíes que aquí hallo haver venido a dogmatizar y enseñar la secta, y de aquí tomó fundamento y ocassión la jornada que el dicho doctor Sande hizo a Bomei, adonde fue adereçado aunque de paz y con vandera blanca, y reçibido de guerra por el Rey Soltán Lexar, y forçossamente ubo de pelear y se retiraron los moros y entraron la çiudad los christianos y hallaron que avía mandado el Rey matar y avían muerto a Martín, yndio prinçipal, uno de los embaxadores, y el otro, llamado Simagate de Balayán, que eran vasallos de V. M., de esta isla de Luzón, lo hallaron presso y para justiçiarle, y lo sacaron de las cárçeles los españoles, y él y otros que fueron tomados en las galeras de Bomei declararon lo que passava, y cómo avían los moros rompido las cartas y muerto al embaxador a puñaladas, burlando de las cartas y de quien las escrivia. En esto es de notar que los embajadores de iure gentium deven ser hospedados y venerados y guardados de los enemigos adonde van como una cosa sagrada y sancta: in l. finali ff., De legationibus ${ }^{93}$, ibi, si quis legatum hostium pulsasset, contra ius gentium id commissum esse existimatur, quia sancti habentur legati. Y aun dize el testo allí que el que a los embaxadores legados tocare, deve ser entregado a la voluntad del general del campo contrario, cuyo era el embaxador a quien maltrataron, por ser como está dicho inviolables: in lege Sanctum $\S 1^{\circ}$, ff., De rerum divisione ${ }^{94}$. Para lo mismo es la ley 9, tt. 25, pda. 7: “Magüer los mensajeros vengan de tierra de enemigos, tenemos por bien e mandamos que todo mensajero que venga a nuestra tierra, quier sea christiano o moro o judío, que venga y esté y vaya seguro y salvo por todo nuestro señorío". Los doctores en las mismas leyes los llaman ambasiatores, y esto también dize açerca de la seguridad dellos el maestro Victoria in Relectione De In-

91. Del ár. šayj, jeque, prohombre.

92. Más bien alaçala, nombre árabe de la oración.

93. Lib. 50, tít. 7, 1. 17.

94. Lib. 1, tít. 8, 1.8 . 
dis insulanis ${ }^{95}$, pag. 361, y hazen gran recomendación dellos Fortunio Garsía in Repetitione legis Conventionum, ff. De pactis ${ }^{96}$, nu. 20, et seq., in vol. 1 Repetitionum, fol. 391; Matheus de Afflictis, in tt. Quae sint regaliae, fol. 186, nu. 60. Y era causa esta offensa para hazer la guerra, como lo dize Lucas de Penna in l. $1^{a}$ C. Ut rustici ad nullum obsequium, lib. ii, fol. 178; idem Lucas in lege unica Cod. Ut annorum usus inscio principe, lib. ii, fol. mihi 153, col. 2, adonde contando treze causas de guerra justa, pone la sexta diciendo, si iniuria irrogatur principi vel eius legato, y alega la guerra que hizo David contra el Rey Hanón, que avía raído las barbas de los mensajeros. Lo mismo tiene Matheo de Afflictis in tt. Hic finitur lex Friderici, in cap. Domino guerram, nu. 12, in usibus Feudorum, fol. 54, col. 1, in lib. II Regum, cap. 10, 11 et cap. 12. Y esta causa misma de guerra justa pone mejor Castro, De iusta hareticorum punitione, lib. 12, cap. 14, et est causa 7, fol. 127. Y cuenta como aquel Rey Hanón de los Amonitas hizo a los legados y mensajeros de David raerles las mitades de las barbas y cortarles las vestiduras hasta donde quiso vergonçosamente. Viene grandemente al propósito la parábola de Jesuchristo nuestro Señor acerca de los convidados Matt., cap. 2297, ibi, Reliqui vero tenuerunt servos eius, et contumeliis affectos occiderunt; rex autem cum audisset, iratus est, et missis exercitibus suis, perdidit homicidas illos, et cioitatem illorum succendit. Assí que el doctor Francisco de Sande tuvo bastante causa y razón para satisfazer la injuria, pues fue a combidar de paz para la fee cathólica, y tan enemigos son los Bornéi, que aviendo traydo el doctor Sande un hermano del Rey que se dezía... ${ }^{98}$ éste casó una hija que traxo con el dicho don Agustín Alcandora que como dixe fue presso por él en tierra de su madre, y aviendo ydo y buelto a Borney a ver a su hermano el Rey, lo mandó matar y fue muerto por que havía tomado parentesco con hombre baptizado; et de talibus ambasiatoribus plura docet Lucas de Penna in rub. ${ }^{a}$ C. De legationibus, lib. 10, fol. 100.

30. Caso es muy de sentir el coraçón christiano español que en los tiempos pasados, como dize el arzobispo de Florencia, parte 2, fol. 109, los mahometanos oviesen echado y despojado christianos de España, y los aliados de Aygolando pagano, príncipe de los exérçitos infieles fue contra Carlo, Rey de Françia, y congregó innumerables gentes, sarraçenos, mauros, moabitas, ethíopes, parthos, africanos, persas, el Rey de Arabia, y el de Alexandría, y el Rey de Buxía y de Algarve y de Berbería y de Meca y el Rey de Sevilla y el de Córdova, y llegó hasta Gascones y todo esto contra christianos, aunque fueron vencidos los moros; y aora lo que digo que a de sentirse es contradezir algunos estas conquistas de moros discípulos y desçendientes de aquellos enemigos comunes de la yglesia, y de creer es que de los expelidos de las Españas por los señores Reyes Cathólicos, que serian entre judíos y moros más de quatrocientas y veynte mill ánimas, algunos y muchos dellos vinieron por estos arrabales del mundo, y a de durar la enemistad de sus deçendientes y disçípulos como la tuvieron sus mayores ut supra refiere la cantidad que digo y alega autores Albertino, in rubrica De haereticis, q. 3 , nu. 6.

31. En dos dudas dexaré de dar mi voto por aora aunque estoy rresuelto hasta que se determinen por sentençias; y es la una si los mahometanos serán compelidos a pagar los diezmos a la yglesia; y la otra duda es si a los dichos podrán imponerse doblados tributos que a los gentiles simpliciter.

\footnotetext{
95. Sec. III, núm. 8.

96. Lib. 2, tít. 14, 1. 5.

97. Vers. 6-7.

98. Sigue un espacio en blanco.
} 
32. Por ser ponderaçión digna de notar diré que los pontífiçes Romanos, teniendo como perdido o entretenido su derecho açerca de su señorío y superioridad temporal, se començó a recobrar por el papa León $3^{\circ}$ y en tiempo del Emperador Carlo Magno, devió ser año de 800, y este pontífiçe començó esta preeminencia de juzgar Emperadores y Reyes, y Gregorio $5^{\circ}$ la perfiçionó, y perteneçe a los pontífiçes por lo que yo tengo dicho. Y porque en efeto son vicarios en la tierra de aquél por quien reynan los Reyes y se goviernan por justas leyes las provincias, y assí lo dize la Historia Pontifical, lib. 4, fol. 187 y fol. 236, y los otros historiadores, y en su coronación los Emperadores juran a los pontifiçes la fidelidad y la sujeçión in cap, Tibi domino, 63 distinct. ${ }^{99}$; et imperatores et reges habent iurisdictionem a Papa, ut in cap. Cum ad verum ventum est", 96 distinct. ${ }^{100}$; in cap. Alius 15, q. ${ }^{6}{ }^{101}$; et plura supra allegavi ad quae me remitto.

[c.] Con sola una cosa que diré, dexaré esta prolixidad de mi carta, y es traer a la memoria de V. M. las exhortaçiones y requerimientos que el pontifiçe Alexandro 6 hizo a los señores Reyes Cathólicos y a sus suçessores quando conçedió la bula, recomendándoles la prosecuçión de la conversión de estos miserables, rogándoselo por el baptismo que reçibieron y por las entrañas de Jesuchristo, posponiendo los peligros y trabajos y gastos, ibi, hortamur vos quam plurimum in Domino, et per sacri lavacri susceptionem, qua mandatis apostolicis obligati estis, et viscera misericordiae Domini nostri Iesu Christi attente requirimus, ut cum expeditionem huiusmodi omnino prosequi et assumere prona mente orthodoxae fidei zelo intendatis, populos in huiusmodi insulis et terris degentes ad Christianam religionem suscipiendam inducere velitis et debeatis; nec pericula nec labores ullo umquam tempore vos deterreant, firma spe fiduciaque conceptis, quod Deus omnipotens conatus vestros feliciter prosequetur", etc. Con esto se dixo que avía V. M. muy bien y cathólicamente respondido al virrey don Martín Enrríquez, el qual desde México avía escripto que pues hasta entonçes era y avía sido más la costa que el provecho de estas yslas, que sería bien despoblarlas. Dios tendrá el cuydado de gratificar tan esclareçidos serviçios como el dicho pontífice lo profetizó diciendo, Deus omnipotens conatus vestros feliciter prosequetur.

—. En la çiudad de Manila, de las Yslas Philipinas, 20 de Junio, día de Corpus Christi, año de 1585.

Sacra Cesárea Magestad Real,

besa los pies de V. M, su menor criado y más humilde s.

$$
\text { Li. }{ }^{\text {ado }} \text { M. }{ }^{\text {or }} \text { d'Ávalos }
$$

[rúbrica]

99. Decreto de Graciano, primera parte, dist. 53, c. 33.

100. Ibid., dist. 96, c. 6.

101. Ibid., segunda parte, causa 15, g. 7, c. 3 . 


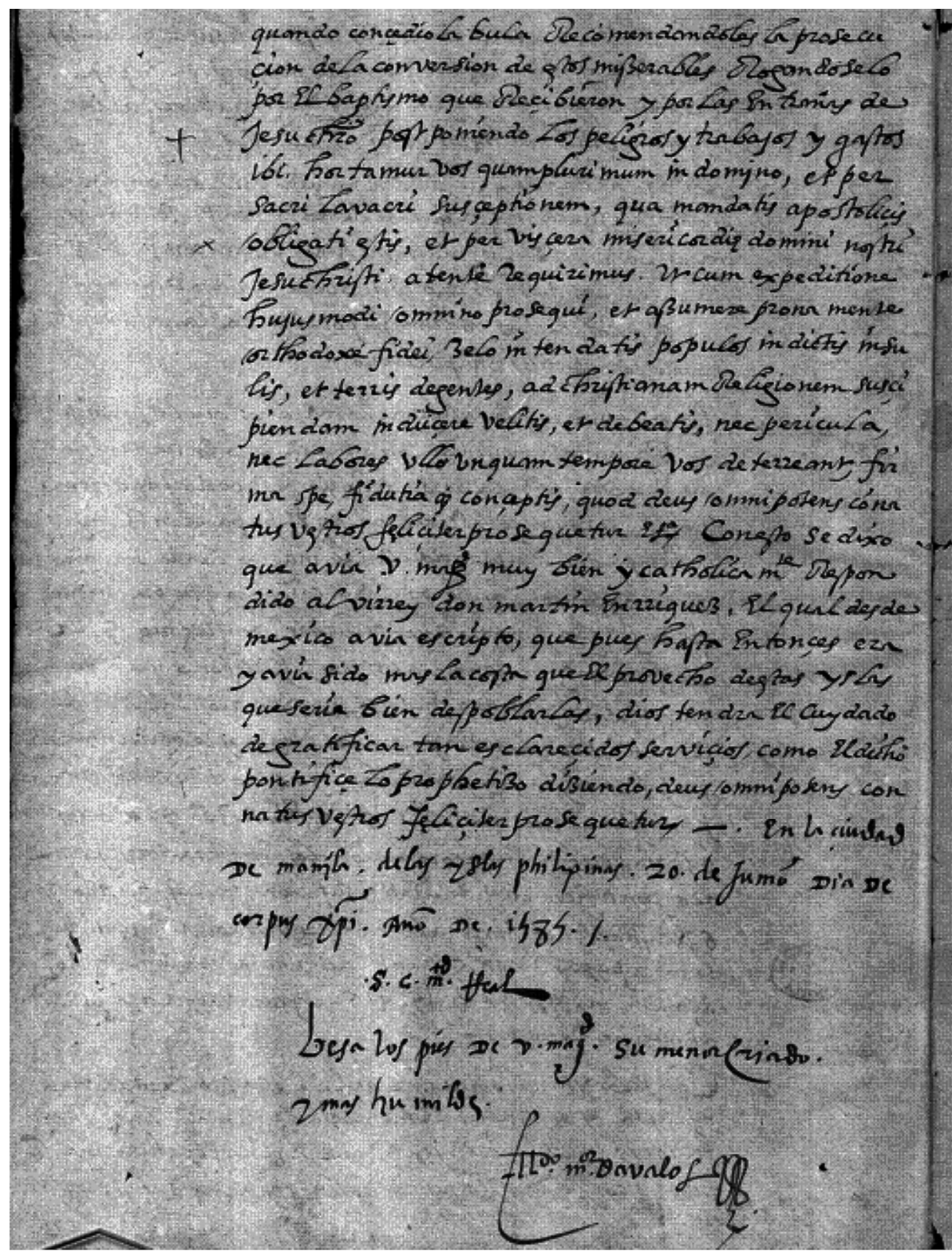

Última página de la Primera carta con la firma y rúbrica de Melchor de Ávalos. 


\section{RESUMEN}

Continuación del trabajo «Moriscos peninsulares, moros filipinos y el islam en el extremo oriental del imperio español: 1. Estudio y edición de la Segunda carta para la S.C.M.R acerca de los mahometanos de las Philipinas de Melchor de Ávalos (1585)», publicado en el volumen anterior de esta misma revista. En esta ocasión se publica el primer memorial enviado por Melchor de Ávalos el 20 de junio de 1585 a Felipe II, con una nota introductoria.

Palabras clave: Melchor de Ávalos, Islam, moriscos, moros, Filipinas, polémica antiislámica, derecho canónico.

\section{ABSTRACT}

This is the second part of the article «Moriscos peninsulares, moros filipinos y el islam en el extremo oriental del imperio español: 1. Estudio y edición de la Segunda carta para la S.C.M.R acerca de los mahometanos de las Philipinas de Melchor de Ávalos (1585)», featured in the last issue of this journal. We publish in the present the First Letter sent by Melchor de Ávalos to the Spanish King Felipe II in June 20, 1585, published with an introductory note.

Key words: Melchor de Ávalos, Islam, moriscos, moros, Philippines, antiIslamic debate, canon law. 